\title{
Progress in exosome associated tumor markers and their detection methods
}

\author{
Mengjiao Shen ${ }^{1,2 \dagger}$, Kaili Di ${ }^{1+}$, Hongzhang He ${ }^{3}$, Yanyan Xia ${ }^{1}$, Hui Xie ${ }^{1}$, Rongrong Huang ${ }^{1}$, Chang Liu' ${ }^{1}$, Mo Yang ${ }^{4 *}$, \\ Siyang Zheng ${ }^{5^{*}}$, Nongyue $\mathrm{He}^{6^{*}}$ and Zhiyang $\mathrm{Li}^{1^{*}}$ (D)
}

\begin{abstract}
Exosomes are secreted by cells and are widely present in body fluids. Exosomes contain various molecular constituents of their cells of origin such as proteins, mRNA, miRNAs, DNA, lipid and glycans which are very similar as the content in tumor cells. These contents play an important role in various stages of tumor development, and make the tumor-derived exosome as a hot and emerging biomarker for various cancers diagnosis and management in non-invasive manner. The present problems of exosome isolation and detection hinder the application of exosomes. With the development of exosome isolation and detection technology, the contents of exosomes can be exploited for early cancer diagnosis. This review summarizes the recent progress on exosomeassociated tumor biomarkers and some new technologies for exosome isolation and detection. Furthermore, we have also discussed the future development direction in exosome analysis methods.
\end{abstract}

\section{Development on exosome tumor markers}

Extracellular vesicle (EV) includes exosomes, microvesicles and apoptotic bodies. These vesicles have different size and biogenesis. Exosomes are complex 20-100 nm vesicles and generate in a way that intracellular multivesicular bodies (MVBs) containing intraluminal vesicles (ILVs) fuse with the plasma membrane [1]. Larger vesicles, microvesicles $(100 \mathrm{~nm}-1 \mu \mathrm{m})$ and apoptotic bodies $(1-5 \mu \mathrm{m})$, are released directly from the budding and fission of the plasma membrane [2]. In the past decades, researchers have become increasingly interested in the role of EVs, especially exosomes, in diseases.

\footnotetext{
*Correspondence: Mo.Yang@polyu.edu.hk; siyangzheng@cmu.edu; nyhe@seu.edu.cn; lizhiyangcn@qq.com

${ }^{\dagger}$ Mengjiao Shen and Kaili Di contributed equally to this work. ${ }^{4}$ Department of Biomedical Engineering, the Hong Kong Polytechnic University, Hunghom, Kowloon, Hong Kong, People's Republic of China ${ }^{5}$ Department of Biomedical Engineering and Electrical \& Computer Engineering, Carnegie Mellon University, 5000 Forbes Avenue, Scott Hall 4N211, Pittsburgh, PA 15213, USA

${ }^{6}$ State Key Laboratory of Bioelectronics, School of Biological Science and Medical Engineering, Southeast University, Nanjing 210096, China 'Department of Clinical Laboratory, the Affiliated Drum Tower Hospital of Nanjing University Medical School, Nanjing 210008, China

Full list of author information is available at the end of the article
}

Exosomes contain various molecular constituents of their cell of origin such as proteins, RNAs, DNA, lipid glycans. Therefore, tumor-derived exosomes could tell the physiological and pathological states of parent tumor cells, and emerged to be a hot cancer biomarker in liquid biopsy field [3]. Given the rich molecular composition of exosomes and easy availability of liquid biopsy sample, many researchers [4] are pursuing to develop non-invasive diagnostic methods with higher sensitivity and specificity based on exosome, which has very high potential to help early diagnosis, treatment evaluation, and prognostic analysis of the disease. In this section, we have summarized the application of exosomes in tumor diagnosis based on its amount and molecular compositions.

\section{Level of exosomes in tumor diagnosis}

Studies show that the level of exosomes in plasma was significantly higher in cancers (such as ovarian cancer [5] and non-small-cell-lung cancer [6]) patients than that of healthy controls [7]. Therefore, many researchers hypothesize that levels of exosome in bodily fluid can serve as a potential diagnostic biomarker in cancer patients. Logozzi et al. [8] investigated the amount of 
tumor-derived exosome in mouse cancer model, and it was found that the levels of exosomes was correlated with tumor size. In another study, Liu Q et al. [9] found that level of exosome in plasma increases with tumor stage progression in 208 non-small cell lung cancer (NSCLC) cohort patients $(P<0.001)$. Furthermore, Yasunori et al. [10] isolated and quantified exosomes from plasma in esophageal cancer patients $(n=66)$, and revealed that higher level of exosome was obtained in malignant patient than that of non-malignant patients $(n=$ 20) $(P=0.0002)$. Additionally, both of Liu et al. [9] and Taylor et al. [5] found that the level of exosome in plasma could be a prognostic biomarker in non-smallcell lung cancer and ovarian cancer, in which higher level of exosome is an indicator of poor prognosis. With the interesting finding from those clinical studies, the states of cancer development can be predicted by analyzing the levels of exosomes in biofluid samples. However, the sensitivity of analyzing cancer and cancer staging was highly negated by the high background signal from high level of normal cell-derived exosomes. Therefore, it is very hard to make a cut-off line in cancer diagnosis if we count the level of total exosome in plasma. However, the sensitivity and specificity of cancer diagnosis should be significantly enhanced if tumor-derived exosome could be selectively isolated or enriched from bodily fluid.

\section{Exosome proteins in tumor diagnosis}

Exosome cargos contain rich information of proteins, such as skeletal protein, secretory associated protein etc. Interestingly, tumor-derived exosomes also contain proteins from their mother cells, making them an attractive biomarker for cancer diagnosis. Extensive studies found that exosome surface protein, intrinsic protein, and protein modification are significant biomarkers with potential clinical applications in cancer diagnosis. Table 1 summarizes the newly discovered protein biomarkers in tumor-derived exosome in recent years.

\section{Protein expression level}

With rapid development of mass spectrometry and other protein identification technologies, many differentially expressed proteins in tumor cells have been discovered. Sandfeld-Paulsen et al. [25] found that CD151, CD171, and tetraspanin 8 are biomarkers for lung cancer diagnosis, those proteins were found to be powerful to distinguish cancer patients from healthy control. In other studies, exosomes were found to have great potential in breast cancer diagnosis. For example, the level of glypican-1 (GPC-1A) was found to be upregulated in 3/4 cancer patients [26]. Exosome protein survivin-2B was found to be a good biomarker in breast cancer diagnosis [27]. In one prostate cancer diagnosis study, it showed that levels of CLDN3 in exosome were higher in patients with Gleason $\geq 8$ tumors than that patients with benign prostatic hyperplasia $(p=0.012)$ and Gleason 6-7 tumors $(p=0.029)$, and higher levels of annexin (CD62, CD81), heat shock proteins (Hsp70, Hsp90) and many signal molecules (TGF- $\beta 2$, TNF- $\alpha$, IL-6 TSG101) were expressed in prostate cancer cell-derived exosome cultured in hypoxic condition than that of normally cultured cells. Additionally, Fu et al. [28] found that level of TRIM3 protein in serum exosomes decreased in gastric cancer patients. TRIM3 plays a role as tumor inhibition in gastric cancer, and TRIM3 knockdown can promote the growth and metastasis of gastric cancer by regulating stem cell factor and EMT regulator. By surveying the clinical studies on protein markers in exosome, most studies detected the levels of protein expression in total

Table 1 Protein markers in exosome-based tumor diagnosis

\begin{tabular}{lll}
\hline Tumor category & Protein markers in exosome & Change in tumorigenesis \\
\hline colorectal cancer & Copine III [11] & up-regulation \\
& CD147 [12] & up-regulation \\
pancreatic ductal adenocarcinoma & GPC-1 [13, 14] & up-regulation \\
Gastric cancer & HER-2/neu, EMMPRIN, MAGE-1, C-MET [15] & up-regulation \\
& TRIM3 [16] & down-regulation \\
Prostate cancer & PSA [17] & up-regulation \\
& ephrinA2 [18] & up-regulation \\
& survivin [19] & up-regulation \\
melanoma & (phospho)Met [20] & up-regulation \\
& Caveolin-1 [21] & up-regulation \\
Renal cell carcinoma (RCC) & MMP-9, DKP4, EMMPRIN, PODXL [22] & Expression alone in the tumor derived exOsomes \\
non-small-cell lung carcinoma & EGFR, KRAS, claudins and RAB-family proteins [23] & up-regulation \\
& CD151, CD171 and tetraspanin 8 [24] & up-regulation \\
\hline
\end{tabular}


exosomes in bodily fluid. But they cannot avoid the interference from protein expressed in normal cellderived exosomes, which decrease the sensitivity and specificity of protein biomarkers in cancer diagnosis. Therefore, technologies for tumor cell-derived subpopulation exosomes enrichment should be pursued as well to increase the sensitivity and specificity of cancer diagnosis.

\section{Protein post-translational modification}

Post-translational modification (PTM) is involved in protein sorting mechanism in exosome. The types of protein modifications in exosome include phosphorylation, ubiquitination, oxidation, myristoylation, GPIanchor, citrullination, glycosylation, and SUMOylation [29]. Recent studies have shown the potential of protein modifications in exosome as a novel biomarker in diagnosis and prognosis of certain diseases. Since exosomes represent their original cancer cells, the level of their phosphorylation in EGFR can be a good biomarker in monitoring anti-tumor treatment effect [30]. Tao et al. [31] found that 144 of these phosphorylated protein levels in exosome were significantly elevated in cancer patients by comparing 30 breast cancer patients with 6 healthy control patients. Changes in glycosylation are very common in many types of tumor-derived exosomes. $\mathrm{N}$ - and O-glycosylated GPI-anchor CD24 in exosome is an established marker for poor prognosis in ovarian and other carcinomas [32, 33]. And bisecting GlcNAccontaining-glycans and high mannose glycans were found to be ovarian cancer biomarkers via glycomics analysis of EVs glycoproteins from ovarian cancer cells $[34,35]$. Increased levels of glycosylation are often associated with changes in tumor aggressiveness. GlcNAcylation of many exosome proteins were found significantly increased in EVs from metastatic colorectal cancer cells [36], and this phenomenon of highly glycosylated extracellular matrix metalloproteinase (EMMPRIN) was observed with increased concentration in metastatic breast cancer as well [37]. Therefore, protein modification in exosome provides a totally new path for cancer diagnosis. However, due to the tremendous challenge in PTM identification technology, clinical evidence of exosome protein PTM needs further investigation.

\section{Exosome nucleic acids in tumor diagnosis}

In April 2019, the research team of Robert J. Coffey reevaluated the contents of exosomes and concluded that small cell extracellular vesicles (sEVs) do not contain DNA. A possible explanation is that different methods of exosome extraction are used in different studies, which in turn leads to differences in the content of exosomes and the subgroup of exosomes. Too strict an exosome isolation strategy may result in the loss of DNA- containing vesicles, which are too low to be detected. Recently, many studies have shown that DNA is detected in exosomes. Akira Yokoi et al. showed that genomic DNA (gDNA) and nucleoprotein exist in exosomes, and revealed exosome DNA potential diagnosis biomarker of ovarian cancer [38].

Recent studies on extracellular RNA (exRNA) including miRNA, long non-coding RNA (lncRNA), circRNA and tRNA-derived small RNA (tsRNA) have highlighted the potential of these biomolecules and vehicles as molecular signatures of disease, especially on prominent paradigm shift in the field of oncology. Although the nature of those RNAs in exosomes is not quite clear, much effort has been devoted to investigate their clinical application in cancer diagnosis. For example, high level of miR-105 in exosome can be an indicator of tumor metastasis and disease diagnosis [39]. Scientists also found increased level of LISCH7 mRNA in plasma EVs from colon cancer patients [40]. The tsRNA content in exosome has also become an attractive nucleic acid marker in recent years. Lei Zhu et al. found a large number of tsRNAs in exosome and some tsRNAs were significantly increased in plasma exosomes of liver cancer patients [41]. The nucleic acid biomarkers in exosome for tumor diagnosis are summarized in Table 2.

\section{Exosome lipids in tumor diagnosis}

The lipids in exosomes are not only a part of their structure, but their diagnostic value in tumors has been continuously investigated in recent years. A recent study found that there are significant differences of phosphatidylserine (PS) 18:1/18:1 and lactosylceramide (d18:1/16: 0 ) in exosomes between prostate cancer patients and healthy individuals. Furthermore, combinations of these lipid species and PS 18:0-18:2 distinguished the two groups with sensitivity of $93 \%$ and specificity of $100 \%$ [64]. One study found that the levels of $27-\mathrm{OHC}$ in exosomes from ER+ breast cancer cell line (MCF-7) were significantly higher than exosomes derived from estrogen receptor (ER-) breast cancer cell line (MDA-MB231), other control exosomes (non-cancerous cell line HEK293 and human pooled serum) by employing capillary liquid chromatography-mass spectrometry. However, the oxysterol profile in exosome did not reflect the cytoplasmic oxysterol profiles of the origin cells, in which cytoplasmic 27-OHC was low in ER+ MCF-7 cells and high in MDA-MB-231 cells [65].

\section{Exosome enrichment methods}

Exosomes do not exist alone in nature, as they often coexist with cell debris, proteins, lipids, and nucleic acids in the blood and cell supernatant. Non-destructive isolation of exosome from complex biological fluid while preserving their structure and function integrity is an 
Table 2 Nucleic acid biomarkers in exosome for tumor diagnosis

\begin{tabular}{|c|c|c|}
\hline Tumor category & Nucleic acid markers in exosome & Change in tumorigenesis \\
\hline Pheochromocytoma and paraganglioma. & dsDNA with RET, VHL, HIF2A, and SDHB mutations [42] & mutation \\
\hline \multirow[t]{3}{*}{ Pancreatic cancer } & miR-1246, miR-4644, miR-3976 and miR-4306 [43] & up-regulation \\
\hline & miR-17-5p and miR-21 [44] & up-regulation \\
\hline & circ-IARS (RNA) [45] & up-regulation \\
\hline \multirow[t]{3}{*}{ Lung cancer } & miR-378a, miR-379, miR-139-5p, and miR-200b-5p [46] & up-regulation \\
\hline & let-7 g-5p, mir-24-3p, mir-223-3p [47] & up-regulation \\
\hline & mir-7-5p, mir-424-5p [47] & $\begin{array}{l}\text { up-regulation (exosome in } \\
\text { bronchoalveolar lavage) }\end{array}$ \\
\hline Primary central nervous system lymphoma & miR-21 [48] & up-regulation \\
\hline Glioblastoma multiforme & RNU6-1 (noncoding RNA), miR-320, miR-574-3p [49] & up-regulation \\
\hline Endometrial cancer (EC) & hsa-miR-200c-3p [50] & up-regulation (exosome in urine) \\
\hline Cervical squamous cell carcinoma & miR-221-3p [51] & up-regulation \\
\hline \multirow[t]{2}{*}{ Bladder cancer } & IncRNA (MALAT1, PCAT-1 and SPRY4-IT1) [52] & up-regulation (exosome in urine) \\
\hline & IncRNA PTENP1 [53] & down-regulation \\
\hline Urothelial carcinoma of the bladder & Circ RNA circPRMT5 [54] & up-regulation \\
\hline \multirow[t]{2}{*}{ Gastric cancer } & circ-KIAA1244 [55] & down-regulation \\
\hline & LncRNA HOTTIP [56] & up-regulation \\
\hline \multirow[t]{2}{*}{ Colorectal carcinoma } & LncRNA UCA1 [57] & down-regulation \\
\hline & miR-6803-5p [58] & up-regulation \\
\hline Pheochromocytomas (PCCs) and paragangliomas (PGLs) & RET, VHL, HIF2A, and SDHB [42] & mutations \\
\hline \multirow[t]{3}{*}{ Hepatocellular Carcinoma } & mir-21 and mir-144 [59] & up-regulation \\
\hline & LINC00161 [60] & up-regulation \\
\hline & mRNA hnRNPH1 [61] & up-regulation \\
\hline (HCV-related) & IncRNA-HEIH [62] & up-regulation \\
\hline Female patients & IncRNA Jpx [63] & up-regulation \\
\hline Liver cancer & $\begin{array}{l}\text { tRNA-ValTAC-3, tRNA-GlyTCC-5, tRNA-ValAAC-5 } \\
\text { and tRNA-GluCTC-5 [41] }\end{array}$ & up-regulation \\
\hline
\end{tabular}

indispensable step for downstream exosome analysis. Webber et al. proposed that $3 \times 10^{10} \mathrm{EVs}$ per $\mu \mathrm{g}$ of protein indicated high purity of EVs [66]. The main challenge in isolating exosomes comes from their small size. The current mainstream isolation methods are classified into five groups [67] which include differential ultracentrifugation-based techniques, size-based techniques, immunoaffinity capture-based techniques, precipitation, and microfluidics-based techniques. Many literatures $[67,68]$ have detailed the various isolation techniques, and performance parameters such as exosomes recovery efficiency, assay time and sample volume, bulky instrument. In this section, we have surveyed the recent progress in exosome isolation technology.

\section{Size-based exosome isolation methods Gel exclusion chromatography}

Gel exclusion chromatography is a technique that separates the sample by particle size. It often uses Sepharose $2 \mathrm{~B}$ or $\mathrm{CL}-4 \mathrm{~B}$ to pack the column, then every fraction was collected for subsequent purification. Size based gel exclusion chromatography is found to work well in isolating exosome from contaminating plasma proteins and high-density lipoproteins (HDL). A recent study employed the size exclusion chromatography to extract exosome from the blood, and it showed that the exosomes have good purity [69] with low yield. Moreover, studies also showed that that the exosomes isolated from gel exclusion chromatography have higher biological function compared to that of ultracentrifugation [70].

\section{Ultrafiltration}

Ultrafiltration (UF) uses ultrafiltration membrane with different aperture to isolate exosomes from protein and other biological macromolecules, and exosomes can be enriched on the ultrafiltration membrane after centrifugation [71]. The commonly used pore size ranges from 1 to $100 \mathrm{~nm}$ [72], and the solid the adhesion is, the harder the elution. Hence, drawbacks of UF include challenges in washing away contaminating proteins and elution of 
exosomes from the filtration membrane. All the above directly negates the yield and purity of exosome. The coated (hydrophilized) membranes can enhance the filtration efficacy to some degree. Merchant et al. [73] utilized microfiltration to isolate human urinary exosomes and found that microfiltration was comparable to UC and will preserve the integrity of exosome structure.

\section{Deterministic lateral displacement (DLD) pillar arrays}

Wunsch et al. [74] developed nanoscale DLD (nanoDLD) arrays which can accurately isolate exosome from 20 to $110 \mathrm{~nm}$ based on silicon chip. When the particle injection stream goes through the array, particles with different sizes will travel in different trajectories, in this case, for a given gap size between pillars, particles with different diameters display different migration angles. Particles with diameter $D_{P}$ (particle diameter) $\geq D_{C}$ (critical diameter) will be displaced laterally across an array in a bumping mode, with a maximum angle. Particles with $\mathrm{D}_{\mathrm{P}}<\mathrm{D}_{\mathrm{C}}$ follow the laminar-flow direction in a zigzag mode, with a mean angle of zero with respect to the array. This method demonstrated its high throughput and high resolution in small size particles isolation. However, it is inevitable that the virus and lipoprotein with the same size as exosome will be co-isolated in complex blood.

\section{Viscoelasticity-based microfluidic system}

This is a challenge to separate exosomes from other vesicles such as microvesicles. Liu et al. [75] showed one method which is mainly based on fluid viscoelasticity from PEO (polyethylene oxide). This method can move exosome and large EV to microchannel centerline at a size-dependent rate. The separation mechanism is shown in the Fig. 1. It combines the advantage of both microfluidics and hydromechanics, and this isolation method achieved a high purity $(>90 \%)$ and recovery $(>80 \%)$.

\section{Acoustofluidics-based isolation method}

The platform [76] is a combination of acoustics and microfluidics that directly isolate exosomes from various biological fluids. As shown in Fig. 2, this device is consisted of two surfaces acoustic wave (SAW) microfluidic modules, respectively achieving the function of cell removal and exosome purification. Its isolation mechanism is that radiation force $(\mathrm{Fr})$ generated by the SAW field and Stokes drag force $(\mathrm{Fd})$ are proportional to the size of particles or cells. For larger particles, Fr dominates over $\mathrm{Fd}$, making them migrate towards the tilted nodes. By continuously adjusting the input power, the suitable cutoff size for exosome isolation can be obtained. When isolating exosomes from extracellular vesicle mixture,

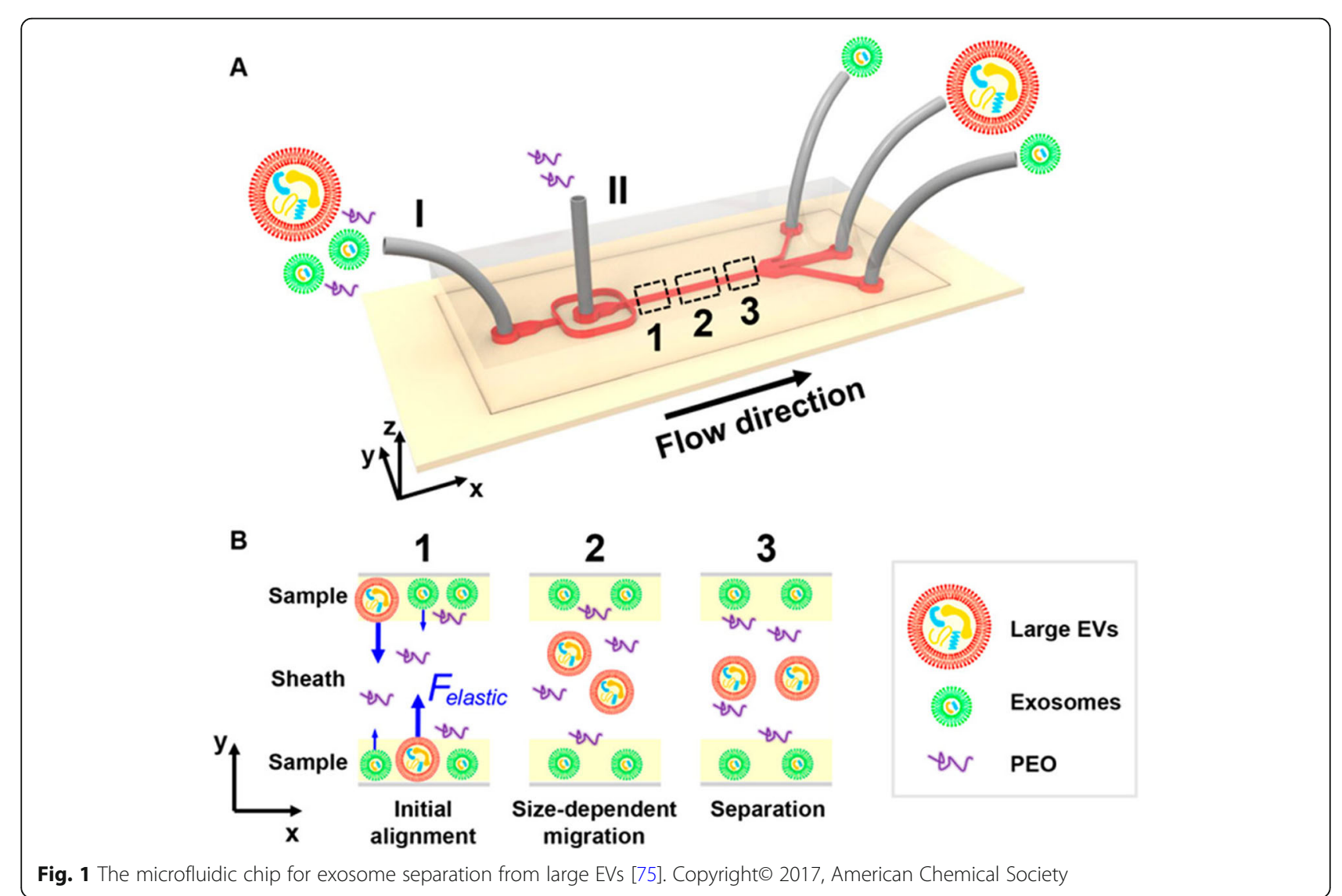




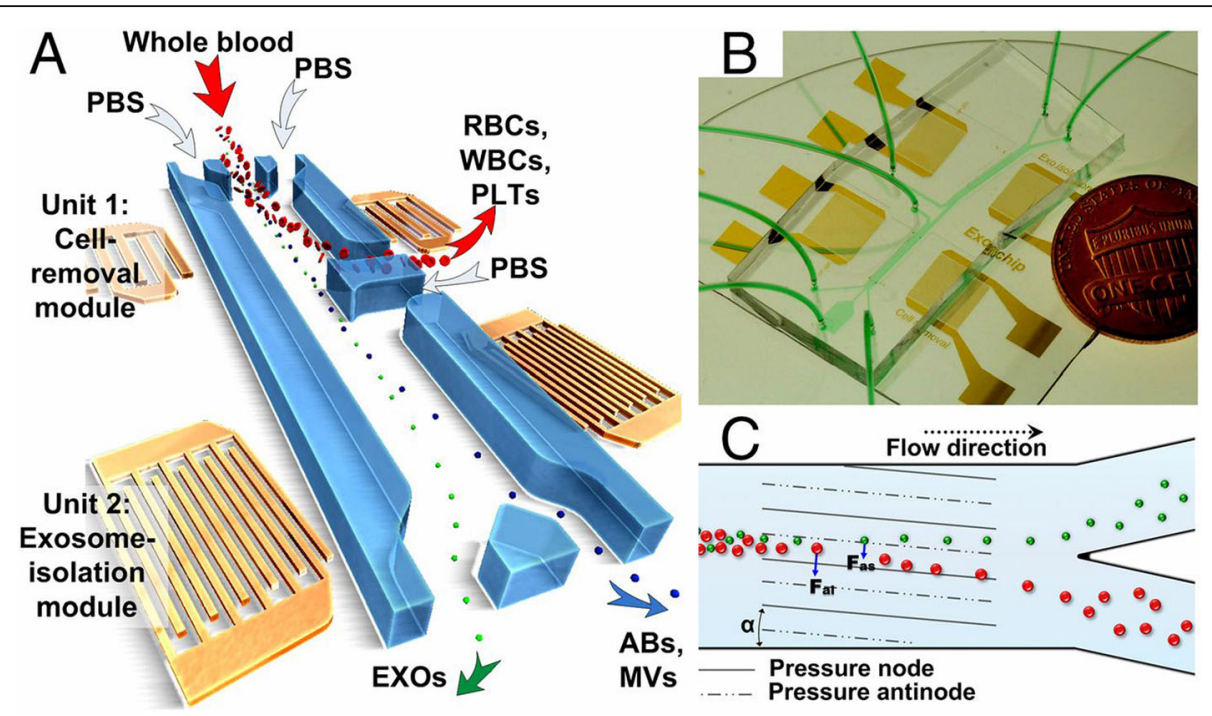

Fig. 2 The platform underlying integrated acoustofluidic device for isolating exosomes [76]

the platform can obtain a purity of $98.4 \%$, while isolating exosomes from whole blood can remove $99.999 \%$ blood cell. The advantages of this platform are rapid, biocompatible, label-free and need no contact.

\section{Affinity-based exosome isolation methods}

Affinity-based isolation methods often use specific agent that bind strongly to exosome surface marker. The affinity method achieves the merit of higher purity over other physical properties-based methods. Differing from conventional beads, the column [77] and paper [78] are able to be served as capture carriers. Tetraspanin proteins like CD63 and CD9 are often chosen as selection tag for such methods. Apart from the well-established antibodies, other biologically active substance like aptamers $[79,80]$, lipid probe, heparin [81], and lectin [82, 83] have also been employed in design of exosome affinitybased isolation method. The main technologies are summarized in this section.

\section{Immune affinity capture (IAC)}

The immune affinity capture technique employs specific antibodies that bind to the surface protein on exosomes. Currently, antibodies have been combined with some new functional nanomaterials and a series of new immunoaffinity isolation techniques have been developed. Apart from magnetic and latex beads, the most commonly used immobilization tools for antibody coating [84] include [78] highly porous monolithic silica microtips [85], graphene foam [86], superparamagnetic nanoparticles [87] and temperature-responsive magnetic nanoparticle [88] to isolate exosomes. It is reported that IAC is the most effective method, and this study shows that the specific marker in exosome isolated by IAC is more than 2-fold higher than that of UC and gradient centrifugation [89]. However, IAC method has high possibility to miss the exosome subpopulations with low expressed surface proteins. To maximize the capture efficiency of IAC [90], we might use a cocktail of the antibodies (such as CD9, CD81, and CD63) to target the surface proteins on exosomes.

\section{Aptamer-based isolation method}

The aptamer-based method has two forms, an oligonucleotide sequence or a short polypeptide. Aptamer recognizes and binds to their targets like antibody with high specificity and affinity, and have been employed in constructing affinity-based isolation of exosomes. For example, a coating agent consisted of EpCAM-affinity peptide aptamer (Ep114) and zwitterionic poly-2methacry loyloxyethyl phosphorylcholine (MPC) polymer has been developed for exosome isolation [79]. This material was coated on silica or polystyrene surfaces, which allows capture of EpCAM $(+)$ exosome. The

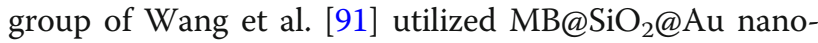
particles decorated with CD63 nucleic acid aptamer to capture exosomes in plasma from cancer patients. Similar studies include use of Vn96, [92, 93] a peptide aptamer has affinity to heat shock proteins (HSP) to capture EVs that express HSP [80]. The study shows that the Vn96 based method obtained higher yield than of UC [93]. Many other peptide aptamers, such as A8 and A17 bind to the different domain of HSP70, peptide aptamer MARCKS-ED and bradykinin (BK) trimer bind to PS [94], peptide aptamer LXY30 targeted $\alpha 3 \beta 1$ integrin has been used to develop exosome isolation technology. All these exosome isolation method might have high potential to isolate specific tumor-derived exosome [95, 96]. 
Due to its high binding affinity toward the protein marker on the surface of tumor-derived exosomes its thermal stability, and commercial availability, the aptamer-based capture methods might have higher potential in exosome isolation compared with antibodybased capture method [97].

\section{Lipid-based nanoprobes (LNP) isolation method}

Rapid magnetic isolation of EV via lipid-based nanoprobes (LNP) is a method that uses NeutrAvidin (NA)coated magnetic sub-micrometre particles to capture lipid probes [DSPE-PEG, biotin-tagged 1,2-distearoyl-snglycero-3-phosphethanolamine-poly (ethylene glycol)] labeled exosomes, which could isolate exosomes in only $15 \mathrm{~min}$ from both of the tumor cell culture or fresh plasma [98]. The highest isolation efficiency is $48.3 \%$ for the whole blood sample. Different from immunoaffinity, this separation method relies on pre-modified lipid probe rather than the exosome-specific membrane protein for exosome enrichment. This method can obtain the exosomes with equivalent purity and quality as ultracentrifugation, but without the need for hours of time and bulk of equipment. The yield of exosome has been determined to be feasible for subsequent DNA and RNA analysis.

\section{Ligand-based isolation method}

Similar as antibody-based affinity capture methods, ligands against specific proteins on the surface of exosomes can also be used to construct affinity-based capture tool for exosome isolation. For example, TIM4 (T-cell immunoglobulin- and mucin-domain-containing molecule) [99] is a protein that bind to phosphatidylserine (PS) in calcium-dependent manner. PS is rich on the surface of exosome [100]. Takeshi et al. modified the magnetic beads with TIM4-Fc as capture reagents. As a result, the method achieved rapid exosome isolation with $4 \mathrm{~h}$. The captured exosomes can be eluted via a chelator such as EDTA, which might hamper the downstream analysis of DNA and RNA. Enzyme-linked immunosorbent assay (ELISA) analysis suggested this method has higher recovery than that of CD9, CD81, and CD63 antibody coated microtiter plate $[100,101]$. Another commonly used capture reagent against PS is annexin V [102]. Its binding to exosomes depends on the presence of calcium ions, and exosome will be eluted in EDTA solution. Heparin is a kind of mucopolysaccharide that block interaction between tumor cell EVs and recipient cell [103]. Heparin-conjugated agarose beads can be used for exosome purification from cell culture media and human plasma using ultrafiltration (UF). The method can reach a recovery of $60 \%$. Leonora et al. [81] described a serials of exosome proteins that have unique matched peptides, and these peptides are likely to be explored in exosome isolation in the future.
Lectin is a carbohydrate-binding protein that binds glycan on glycoproteins weakly but with high specificity. Recently, STL lectin (Solanum tuberosum lectin) was used to isolate exosome from urine [82]. Exosomes isolated according to different tags differ in characteristics. Studies found that vesicles isolated by antibody and lectin exhibited distinct variations in size and surface content [83]. And some studies found that antibody-based isolation methods may destroy the integrity of exosome since the binding affinity is too strong [101].

\section{Charge properties-based methods \\ Alternating current electrokinetic (ACE) microarray chip}

In the isolation force formed by alternating current electric field [104], exosomes and other EVs were pulled in high-field region based on the difference of dielectric properties among different nanoparticles and surrounding fluid. With simple wash, exosomes can be purified from the complex blood sample. Exosomes and other EVs are collected in DEP high-field regions around the edge of microelectrodes. Other large non-EVs components are concentrated in DEP low-field regions between the microelectrodes, which can be washed away and removed. The basic principle is shown in Fig. 3. This technique can directly concentrate and analyze exosome from untreated blood in only $30 \mathrm{~min}$ with $30-50 \mu \mathrm{L}$ sample.

\section{Anion-exchange (AE)-based isolation method}

Phosphatidylserine (PS) on the surface of exosome membrane is negative charged [105]. Based on this characteristics, Chen et al. [106] used AE magnetic beads to directly enrich exosome in plasma. During the exosome isolation, negatively charged exosomes bind with positively charged AE magnetic beads, while impurities like cell debris, large particles and other positive charged protein will be washed away. It is reported that this method can achieve over $90 \%$ recovery efficiency and less protein contaminant than that of ultracentrifugation.

A good exosome isolation method should be compatible with diverse sample matrices and have high exosome recovery with high purity and yield. Multiple encouraging progress has been made in exosome isolation in the presence of overlap in chemical, physical and biological properties between exosome and other extracellular vesicles. All the isolation methods mentioned in the section are summarized in Table 3. The development of ideal isolation technique remains to be a big challenge. Co-isolation of lipoproteins with exosomes is particularly a problem for many sizes or density-based methods in blood plasma samples [116]. Lipid droplets from ruptured cell should be taken into consideration when those surface proteins not specifically expressed on exosomes were chosen for purification. Currently, 


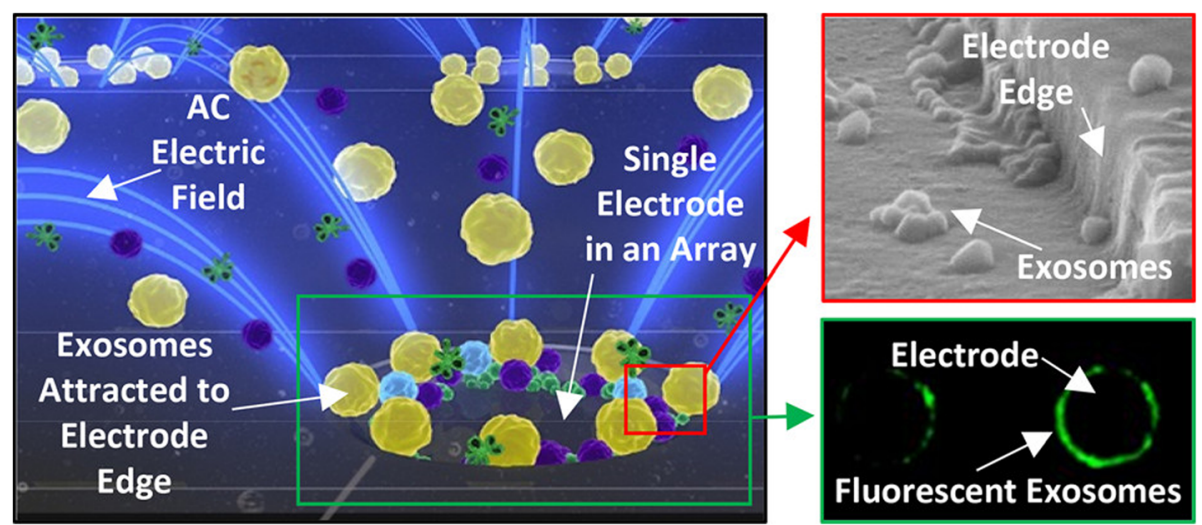

Fig. 3 ACE chip microelectrodes collect exosomes and other microvesicles [104]. Copyright@ 2017, American Chemical Society

ISEV indicates that there is no single best isolation method, and they recommend the choice of exosome isolation method will be based on downstream applications [117]. In the future, those platforms which can integrate various exosome isolation techniques for subsequent analysis will substantially increase efficiency for exosome detection.

\section{Exosome quantification methods}

As mentioned above, the absolute amount of exosome in bodily fluid directly suggests the presence and stage of cancer. There is a variety of techniques currently available for exosome quantification. And there is no consensus that which method is the best option. Exosome quantification can be categorized into two different methods: unspecific counting methods and general quantification methods which are based on common substances in interested exosomes. Unspecific counting methods often obtain an absolute value that can be compared between different studies. Those methods often perform direct counting exosomes one by one based on their physical properties, like optical. It is mandatory to do pre-isolation before analysis. In terms of tumor derived exosome quantification, these widespread substances often refer to various markers with diagnostic value for multiple tumors, like protein, ribonucleic acids etc., as mentioned before.

\section{Unspecific counting methods}

Unspecific determination methods only obtain a rough estimation of the number of vesicles present in sample, and they are limited by primitive purification prior to analysis and various detection threshold setting. Currently unspecific counting techniques include Nanoparticle Tracking Analysis (NTA) [118], Resistive Pulse Sensing (RPS) [119], Tunable resistive pulse sensing (TRPS), Dynamic light scattering (DLS) $[120,121]$ and electron microscopy (EM). The principle, potential advantages and disadvantages of each methods have been discussed and summarized in several reviews [122, 123]. 2017 methodological guidelines [68] from ISEV compared estimated count rate and detectable size range in NTA, RPS, flow cytometry, and EM. Among them, the guideline found out that flow cytometry is able to quantify the number of exosomes and record specific fluorescent signal as particles pass though, and their size can be calculated from the side scattering signal [124]. The mechanism of nanoparticle flow cytometry is almost the same as flow cytometry. In brief, when the particles travel through the fixed laser beam, the nanoparticles would scat the light, and the size distribution would be obtained by analyzing these light signals. Many scientists have focused on in down-regulating detected level of particle size. Owing to relatively small size of exosomes, the light signal difference between the background noise and target particle is quite subtle. Theoretically, lower laser wavelengths can detect smaller particle size. CytoFlex was developed by Beckman Coulter company by introducing violate side scattered light (VSSC) $(405 \mathrm{~nm})$ and Fiber Array Photodiode (FAPD) patented technology. It can reduce the detection limitation to $200 \mathrm{~nm}$. Britain Apogee Company's Apogee A50 Micro [125, 126] can detect about $100 \mathrm{~nm}$ nanoparticles, benefiting more from its excellent light optical technology that can discriminate small vesicles from noisy ones. Using polystyrene or silica beads as standard for determining nanoparticle size is not accurate [68], Apogee A50 Micro can also correct results by combining their optical parameters. Ye et al. [12] developed a high-sensitivity flow cytometry with a EV detection range of $40-175 \mathrm{~nm}$, and further reduced the probe volume to $25 \mathrm{fL}$ (femtoliter) and extended the dwell time when nanoparticles pass through the laser beam to ms (milliseconds). As a result, this method effectively decreased the background signal and enhanced emitted photons. 
Table 3 Comparison of different exosome isolation methods

\begin{tabular}{|c|c|c|c|c|}
\hline Method & & Time & Advantages & Disadvantages \\
\hline \multirow[t]{2}{*}{ Density based methods } & Ultracentrifugation [107] & $130 \mathrm{~min}$ & $\begin{array}{l}\text { Relative high purity, allowing } \\
\text { exosome isolation in large } \\
\text { volume sample }\end{array}$ & $\begin{array}{l}\text { Time consuming, bulk instruments, } \\
\text { high speed rotation may cause } \\
\text { deformation of exosomes. }\end{array}$ \\
\hline & $\begin{array}{l}\text { Density gradient } \\
\text { centrifugation }[108,109]\end{array}$ & $250 \min$ & $\begin{array}{l}\text { Relative higher purity, can } \\
\text { exclude some other EVs. }\end{array}$ & $\begin{array}{l}\text { high requirement for the control of } \\
\text { centrifugal time, centrifugal medium } \\
\text { preparation is complex. }\end{array}$ \\
\hline Precipitation methods & $\begin{array}{l}\text { ExoQuick }{ }^{\mathrm{TM}} \text { and Total } \\
\text { Exosome Isolation }^{\mathrm{TM}} \\
{[110-112]}\end{array}$ & $14-16 \mathrm{~h}$ & $\begin{array}{l}\text { Simple protocol, compatible } \\
\text { with a variety of specimens. }\end{array}$ & $\begin{array}{l}\text { time-consuming, low purity, co- } \\
\text { precipitation of impurities such as } \\
\text { soluble protein }\end{array}$ \\
\hline \multirow[t]{5}{*}{ Size based methods } & Ultrafiltration $[73,113]$ & $140 \mathrm{~min}$ & Simple protocol and time-saving & $\begin{array}{l}\text { Exosomes' blocking or adherence to } \\
\text { the filter membrane holes may cause } \\
\text { the loss of yield. The force applied to } \\
\text { promote the filtration may lead } \\
\text { exosome damage, out of shape. }\end{array}$ \\
\hline & $\begin{array}{l}\text { Gel exclusion } \\
\text { chromatography }[69,110]\end{array}$ & $6-12 h$ & $\begin{array}{l}\text { Simple operation, preserve } \\
\text { integrity of exosomes }\end{array}$ & bulk instrument, relatively low scalable \\
\hline & $\begin{array}{l}\text { Deterministic lateral } \\
\text { displacement (DLD) } \\
\text { pillar arrays [74] }\end{array}$ & $12 \mathrm{~nL} / \mathrm{h}$ & $\begin{array}{l}\text { High resolution, flexible particle size } \\
\text { separation range, no particle labelling, } \\
\text { small sample volumes }\end{array}$ & $\begin{array}{l}\text { Complex parameter settings, low } \\
\text { operability, pre-purification needed, } \\
\text { relative high risk of clogging }\end{array}$ \\
\hline & $\begin{array}{l}\text { MicrofluidicViscoelastic } \\
\text { Flows [75] }\end{array}$ & $200 \mu \mathrm{L} / \mathrm{h}$ & $\begin{array}{l}\text { High purity }(>90 \%) \text { and recovery } \\
(>80 \%) \text {, field-free, label-free, fast, low } \\
\text { cost, cutoff size is regulatable. }\end{array}$ & $\begin{array}{l}\text { PEO is hard to remove and may } \\
\text { influence subsequent analysis }\end{array}$ \\
\hline & Acoustofluidic [114] & $\sim 25 \min$ & $\begin{array}{l}\text { Direct separation from biological } \\
\text { fluids label-free, high yield and purity, } \\
\text { cutoff size is flexible, automation, } \\
\text { high reproducibility, }\end{array}$ & $\begin{array}{l}\text { Aggregation of lipids in blood may } \\
\text { greatly reduce separation efficiency. }\end{array}$ \\
\hline \multirow[t]{4}{*}{ Affinity isolation methods } & $\begin{array}{l}\text { Immune affinity } \\
\text { capture [89] }\end{array}$ & $240 \min$ & $\begin{array}{l}\text { high purity, milder manner for } \\
\text { exosome isolation, preserve structure } \\
\text { integrity of exosome. }\end{array}$ & $\begin{array}{l}\text { overlook the subpopulation without } \\
\text { affinity marker, non-specific binding, } \\
\text { not suit for large scale exosome } \\
\text { purification }\end{array}$ \\
\hline & EpiVeta [79] & $>10 \mathrm{~h}$ & $\begin{array}{l}\text { Peptide aptamer is versatile and } \\
\text { easier to prepare. This coating layer } \\
\text { can be combined with a variety of } \\
\text { solid phase carriers. }\end{array}$ & $\begin{array}{l}\text { Specimens require pre-processing } \\
\text { and the process takes a long time, } \\
\text { lacking verification of body fluid } \\
\text { exosome. }\end{array}$ \\
\hline & Lipid nanoprobe (LNP) [98] & $15 \mathrm{~min}$ & $\begin{array}{l}\text { Fast, high yield, compatible various } \\
\text { downstream analyses of DNA, RNA } \\
\text { and proteins. }\end{array}$ & $\begin{array}{l}\text { lack specificity, other lipid and albumin } \\
\text { in blood could be co-purification, } \\
\text { magnetic bead separation may cause } \\
\text { the shrinkage of nEVs }\end{array}$ \\
\hline & $\begin{array}{l}\text { TIM4-Fc-conjugated } \\
\text { beads }[101,115]\end{array}$ & $4 \mathrm{~h}$ & $\begin{array}{l}\text { high purity, preserve function } \\
\text { of exosome. }\end{array}$ & $\begin{array}{l}\text { purification efficiency decreases when } \\
\text { the volume of the sample is over } 1 \mathrm{~mL} \\
\text { and TIM4. inhibitors (EDTA and citric } \\
\text { acid) existed, The separation step is } \\
\text { complicated and requires pretreatment, } \\
\text { yields vary greatly among different sample }\end{array}$ \\
\hline \multirow[t]{2}{*}{$\begin{array}{l}\text { Charge properties } \\
\text { based methods }\end{array}$} & $\begin{array}{l}\text { Alternating current } \\
\text { electrokinetic microarray } \\
\text { chip [104] }\end{array}$ & $<30 \min$ & $\begin{array}{l}\text { Direct separation from plasma, } \\
\text { label-free, in situ detection, fast }\end{array}$ & $\begin{array}{l}\text { possible contamination of protein } \\
\text { polymers with similar charging properties }\end{array}$ \\
\hline & $\begin{array}{l}\text { anion-exchange (AE)-based } \\
\text { isolation method [106] }\end{array}$ & $30 \mathrm{~min}$ & $\begin{array}{l}\text { direct separation from plasma, } \\
\text { high recovery efficiency (>90\%), } \\
\text { fast, high purity. }\end{array}$ & $\begin{array}{l}\text { Varying salt ion concentration may affect } \\
\text { the structure and function of vesicles } \\
\text { while elution, possible contamination of } \\
\text { protein polymers with similar charging } \\
\text { properties }\end{array}$ \\
\hline
\end{tabular}

ImageStreamX MKII of EMD Millipore company [124] presented the image of particles in the same manner as the optical microscope, which makes it possible to distinguish exosome and other cell debris. The use of charge coupled device (CCD) cameras in the instrument instead of traditional photomultiplier tubes leads to wider dynamic range and less noise. Although ImageStreamX can detect particles as small as $100 \mathrm{~nm}$ with the help of fluorescence imaging, but it is still not possible to direct measure the size of exosomes. Indeed, since fluorescence backgrounds are much lower than scatter, the binding-induced fluorescence can partly resolve this 
problem [127]. Under the fluorescence to sort activated exosome, not only the sensitivity is improved, but also exosome surface molecules can be simultaneously detected. Double labeling with protein- and lipid-specific dyes enables separation of EVs from common contaminants of EVs preparations, such as protein aggregates or micelles formed by unbound lipophilic styryl dyes, which is able to eliminate overestimation of numbers of $\mathrm{EV}$ [85]. Moreover, Groot et al. [128] sorted subsets of EVs differentially labeled with two fluorescent antibodies with high purity by altering nozzle size and sheath pressure. They also found that swarm effects that high concentration particles will severely impair EV quantification and characterization. Multiple objects going through the interrogation point in the same time may be mistakenly counted as one big particles [129]. Therefore, an appropriate concentration with proper flow rate is always needed to ensure a reasonable acquisition rate using flow cytometry for exosome detection.

\section{Quantification based on exosome content}

Proteins present inside of exosomes are inaccessible due to the lipid membrane envelope. Methods in these parts accomplish the quantification by relying on multiple chemical reactions, to transform the tiny vesicles to signals detectable by instrument or human naked eyes. Some of them have integrated the enrichment with quantification, making it possible to perform raw blood analysis. This following section focuses on commercial kits and several remarkable methods developed in the recent years.

\section{Quantification by commercial kits}

There are a lot of quantification kits based on certain substance in SBI exosome, such as EXOELISA-ULTRA, EXOELISA, EXOCET, FLUOROCET, and EXOCET. These methods are either based on colorimetric (fluorescent) method or ELISA as one of the representative products. This technology is based on the fact that Acetyl-CoA Acetylcholinesterase (AChE) is known to be enriched within exosomes [130, 131] from serum, stem cell, cancer cells, mesenchymal stem cell (MSC) etc. Each exosome is not necessarily to contain an equal amount AChE, so the accuracy of this method might be problematic. Moreover, the blood also contains some AchE, in order to avoid errors, the preparation should be completely washed before detection. Of course, some drug like AchE inhibitors should also be taken into consideration [132]. Moreover, Exo-TEST kit from LONZA company is a double sandwich ELISA assay. The special feature of this method is that foreign antibodies (panexosome antibodies) are needed to mediate the adsorption of exosomes and solid phase carriers [133, 134]. Compared with EXOCET, it doesn't need exosome purification. Based on this principle, the affinity and specificity between foreign antibodies and exosome seem to be quite vital for detection accuracy. Similar kits also include ExoQuant, Overall Exosome Capture and Quantification Assay Kit.

\section{Membrane-based quantification approaches}

Quantification methods in this section were carried out based on either membrane modification with chemical group or immune recognition of membrane protein by antibodies. To obtain an absolute number of particles per milliliter, the establishment of a standard curve based on NTA is needed.

Exosome quantification via bivalent-cholesterol labeled DNA anchor for signal amplification The principle of this exosome quantification [135] (Fig. 4) is as follows: The exosomes are specifically captured by anti-CD9 immunomagnetic beads and then DNA anchors labeled with high affinity bivalent-cholesterol spontaneously inserted into exosomes. The anchor's sticky end can trigger a horseradish peroxidase (HRP)linked hybridization chain reaction (HCR). The detection was based on HRP-catalyzed $\mathrm{H}_{2} \mathrm{O}_{2}$ mediated color changes of $3,3^{\prime}, 5,5^{\prime}$ - tetramethyl benzidine (TMB). The method can sensitively detect a concentration of 2200 particles $/ \mathrm{mL}$ with a relative standard deviation of less than $5.6 \%$.

Nanoparticle counting by microscopic digital detection This method [136] utilized digital detection to qualify total exosomes and disease-specific exosomes, which is based on nucleic acid amplification in microchip. Mechanism is shown in Fig. 5. The poly (ethylene glycol) oleyl ether (biocompatible anchor molecule, BAM) conjugated with DNA oligonucleotides is anchored to the lipid bilayer membrane of exosomes through surface self-assembly. The specific antibody (glypican 1 antibody)-DNA conjugate binds to specific subgroups in total exosomes. Exosomes are then assigned to each chamber after removal of free DNA by ultrafiltration unit, ensuring each chamber has one or less exosomes. With fluorescence signal amplification, normal cell-derived exosomes and disease-specific exosomes will emit red and yellow fluorescence in the chamber, respectively. By simple digital detection and Poisson distribution, exosome quantification can be achieved. This method can be combined with various types of established nucleic acid analysis, but this method requires advanced purification for exosome.

Quantum dot-based exosome quantification Currently, there were some studies using quantum dots to quantify exosomes. As shown in the Fig. 6, Boriachek 


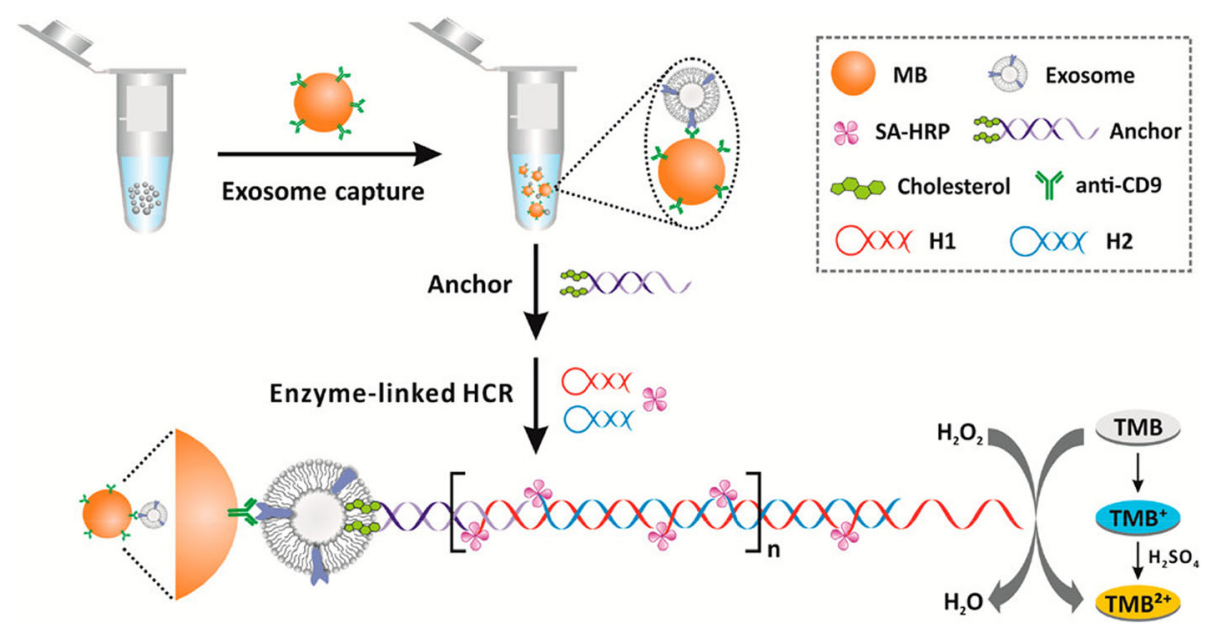

Fig. 4 Exosome quantification by a method based on immunoaffinity separation combined with cholesterol signal amplification [135]. Copyright@ 2017, American Chemical Society

a)

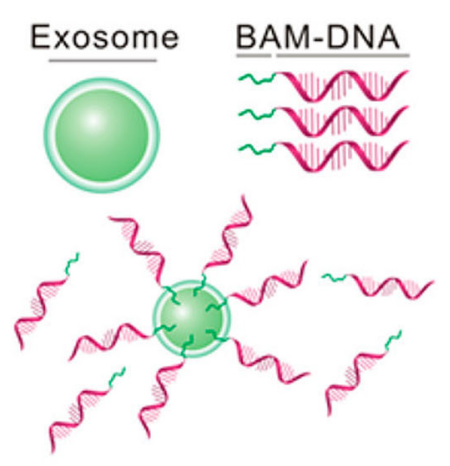

b)

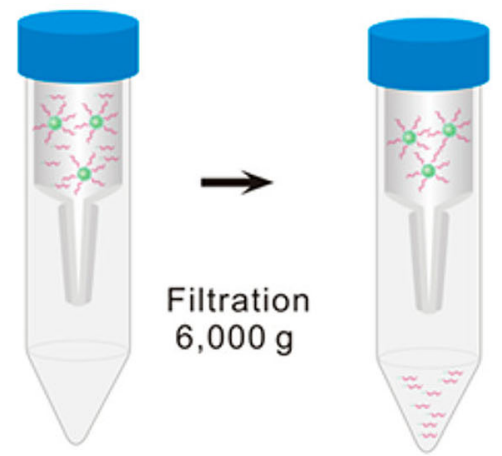

c)
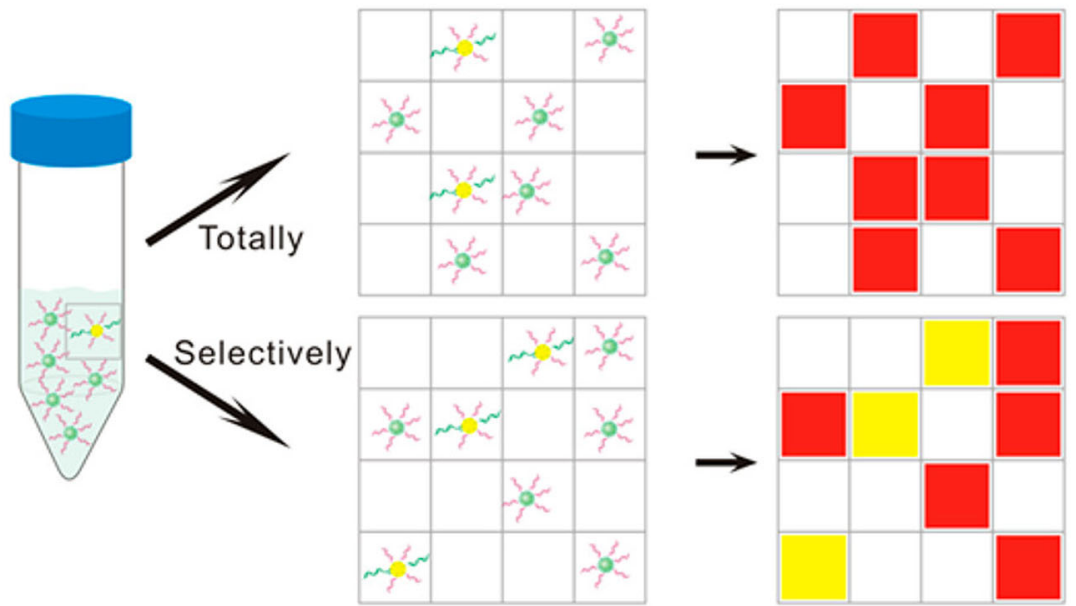

Fig. 5 Exosomes counting by microscopic digital detection via surface-anchored nucleic acid amplification [136]. Copyright@ 2018, American Chemical Society 


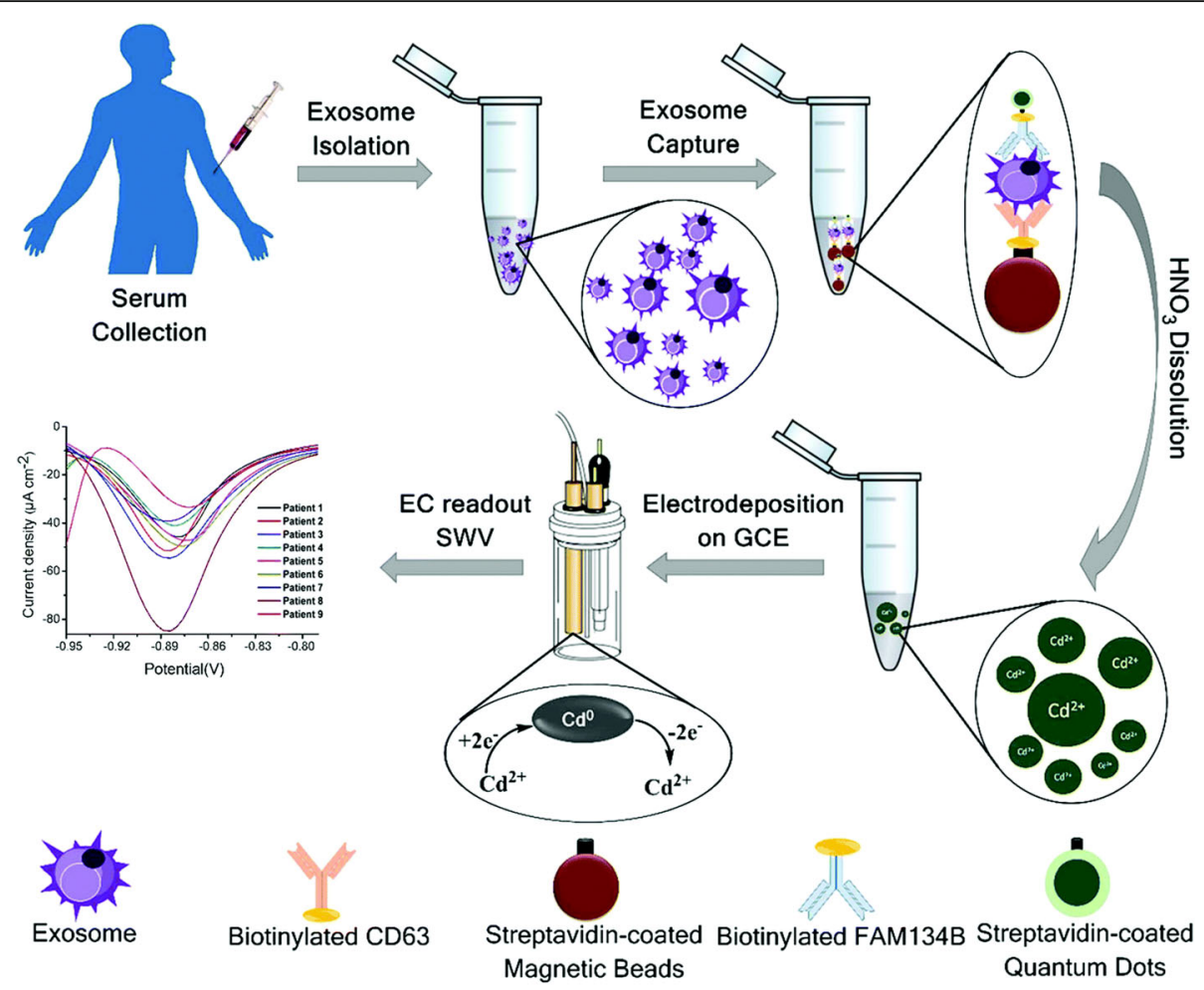

Fig. 6 The isolation and quantify method of cancer-specific exosomes based on CdSeQD [137]. Copyright@ 2017, Royal Society of Chemistry

et al. [137] used exosome-specific antibodies to capture exosomes on magnetic beads, and then used CdSeQDfunctionalized specific antibodies to isolate cancerspecific exosomes. Tumor-specific exosomes were quantified by the detection of CdSeQDs. This method used quantum dots as signal amplifiers and combines voltampere measurement with immune technology to determine disease-specific exosomes. The detection sensitivity of tumor cell lines derived exosomes can reach 100 exosomes $/ \mu \mathrm{L}$, and \%RSD (relative standard deviation) < 0.05. Application of tumor-specific exosome protein antibodies (FAM134B for colon and HER2 for breast cancer) is one of the features of this method, which represented a promising bioassay technique.

Droplet Digital ExoELISA Recent study showed the droplet digital ExoELISA for exosome quantification [138]. As the Fig. 7 shows, exosomes were captured by CD63 antibody coated magnetic beads. Specific antibody (glypican 1 antibody) conjugated with $\beta$-galactosidase which catalyzes the fluorescein-di- $\beta$ - $D$-galacto-pyranoside (FDG), and sandwich ELISA complexes, were isolated into sufficient number of droplets to insure only a single bead is present in a droplet. Fluorescence signals represent the presence of exosomes. Their concentration can be obtained after signals statistical analysis. The detection limit of this technique can reach down to 10 enzymes per microliter (LOD) for labeled exosomes ( 10$17 \mathrm{M}$ ), and the linear correlation with nanosight measurement results can reach 0.995 . This method selects antibodies to purify exosomes, and there are also leak detection for some CD63-low expression exosomes.

\section{Exosome contents detection}

Exosome protein detection

Protein is the core component of human metabolism, acting as a break point for the discovery of novel biomarker for tumor diseases. Traditional protein detection methods like western blot (WB) and enzyme-linked immunosorbent assay (ELISA) are not suitable for routine clinical use with bulky specimens, because of their large sample consumption, cumbersome operation, and special instrument. At present, the detection of exosomes is mainly based on antibody, aptamer and proteomics related mass spectrometry. Antibodies have been used to detect proteins for a long time, and with the rise of aptamers, the shortcomings of its preparation become apparent. The detection method using mass spectrometry is too blind and complicated, which makes it is not suitable for rapid and targeted clinical detection in the future. 


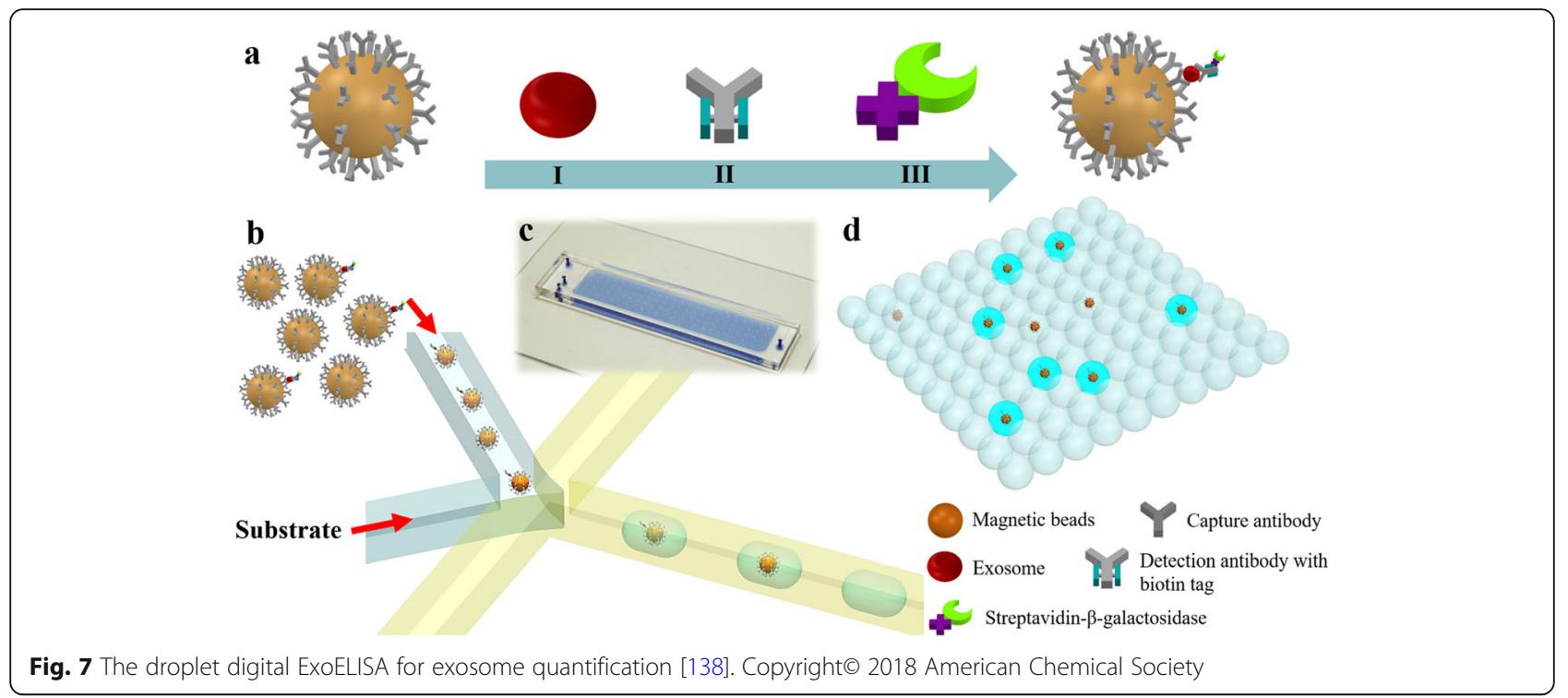

The aptamer detection method for proteins can be combined with mature nucleic acid technology, making it a promising alternative strategy.

\section{Antibody-based methods}

This following part focuses on a series of recently developed antibody-based techniques for exosome protein profile, and the working principle and their performance parameters for each method will be elaborated. Methods in this part often employ the mechanism whereby reporter molecular conjugated antibody is incubated with exosome antigen, in which the antigen amount is proportional to the intensity of reporter signal. Highly specificity and high affinity of antibody are both two key factors in developing a robust immunoassays [139]. The combination of several antibodies can achieve multiple detection of different antigens in one time, which enhances the efficiency of analysis and diagnostic performance, but the possibility also give rise to false positivity due to unspecific binding in multiplexing assay [140]. At the same time, owing to rapid development of exosome biomarkers, there are no accessible antibodies in the market for these biomarkers. The specific markers of exosome subpopulation that track the parent cell is still a big challenge and need further development. The discovery of such makers will provide more detailed information on tumor location. Some classic immunoassay methods are summarized in Table 4. Therefore, we will pass over the introduction for these methods. Table 5 describes some novel antibody-based detection platforms, which includes their principle, dynamic range, and potential advantages and disadvantages.

Western blot (WB) and ELISA Western blot, also known as immunoblotting, is based on basic principle that colors the gel-electrophoresis-treated cells or biological tissue samples by specific antibodies. As a golden standard, WB is the most used in EV research to validate the presence of exosome in purified preparation via its characteristic surface proteins (CD9 and CD63). Processing by lysis solution contains protease inhibitor, exosome solution is then separated by sodium dodecyl sulfate polyacrylamide gel electrophoresis (SDS-PAGE) [158], which is then incubated with primary antibody and secondary antibody after transferring to the membrane. WB provides the information on molecular weight of target protein.

ELISA is another commonly used method for qualitative and quantitative protein detection based on antigenantibody specific binding. As a classic method in immunology, it can be performed in multiple formats, like sandwich method, indirect method, and competition method. Compared with WB, ELISA is faster, easy to handle, more likely to adapt to throughput manner, but it has large variability.

Alternating current Electrokinetic chips This technique [159] pulls nanoparticle like exosomes to the edge of a tiny electrode from other complex blood substance while on alternating current. Large cell and debris will then be washed away with exosome left behind at the effect of alternating electric field. This step can be completed in only 20 mins, with only $25 \mu \mathrm{L}$ plasm or serum without any dilution. Scientists add specific antibody targeted to CD63 or glypican-1 (markers of pancreas ductal carcinoma) labeled with fluorescence. Bright color circle is formed by antibody binding to exosome distributed around microelectrode after incubation and washing, which can then be seen under the microscope once the CD63(+) or glypican-1(+) exosomes exist. The total time 
Table 4 Classic immune analysis techniques for exosome proteins

\begin{tabular}{|c|c|c|c|c|c|c|c|}
\hline Method & Basic principle & Signal output & $\begin{array}{l}\text { Sample } \\
\text { volume }(\mu \mathrm{L})\end{array}$ & $\begin{array}{l}\text { LOD } \\
\text { (particles/mL) }\end{array}$ & $\begin{array}{l}\text { Analysis } \\
\text { time } \leq 2 \mathrm{~h}\end{array}$ & Advantages & Disadvantages \\
\hline $\begin{array}{l}\text { Surface Plasmon } \\
\text { Resonance (SPR) } \\
{[141-145]}\end{array}$ & $\begin{array}{l}\text { Binding between EV } \\
\text { and sensor surface } \\
\text { coated with specific } \\
\text { antibody induces } \\
\text { refractive index change. }\end{array}$ & Refractive index & 20 & $10^{7}$ & yes & $\begin{array}{l}\text { Label-free, } \\
\text { monitor binding } \\
\text { between } \\
\text { exosome and } \\
\text { antibody }\end{array}$ & $\begin{array}{l}\text { require special } \\
\text { instrument }\end{array}$ \\
\hline $\begin{array}{l}\text { Fluorescent Immuno } \\
\text { Sorbent Assay (FLISA) } \\
{[90,146]}\end{array}$ & ELISA based method & Fluorescence & 1 & $10^{10}$ & no & High sensitivity & $\begin{array}{l}\text { problem of auto } \\
\text { fluorescence and } \\
\text { fluorescence } \\
\text { quenching }\end{array}$ \\
\hline $\begin{array}{l}\text { Time-Resolved } \\
\text { Fluorescent Immuno } \\
\text { Assay (TRFIA) [147] }\end{array}$ & $\begin{array}{l}\text { Based on long } \\
\text { half-life of europium }\end{array}$ & $\begin{array}{l}\text { Phosphorescent } \\
\text { molecules (like } \\
\text { europium) }\end{array}$ & 100 & $10^{10}$ & no & $\begin{array}{l}\text { More sensitive } \\
\text { than ELISA }\end{array}$ & $\begin{array}{l}\text { europium is } \\
\text { harmful for health }\end{array}$ \\
\hline $\begin{array}{l}\text { Integrated Microfluidic } \\
\text { Exosome Analysis } \\
\text { Platform (IMEAP) } \\
{[84,148]}\end{array}$ & $\begin{array}{l}\text { Combination of MAIA } \\
\text { technique and microfluid }\end{array}$ & Fluorescence & 30 & $10^{8}$ & yes & $\begin{array}{l}\text { More capture } \\
\text { surface than } \\
\text { ELISA, micro } \\
\text { fluid improves } \\
\text { efficiency }\end{array}$ & - \\
\hline $\begin{array}{l}\text { Amplified Luminescent } \\
\text { Proximity Homogeneous } \\
\text { Assay (ALPHA) [149] }\end{array}$ & $\begin{array}{l}\text { EV pulls two beads as } \\
\text { close as } 200 \mathrm{~nm} \text {, accepter } \\
\text { beads uptake } \mathrm{O} 2 \text { from } \\
\text { donor bead after being } \\
\text { activated }\end{array}$ & Emitted light & 5 & $10^{10}$ & yes & $\begin{array}{l}\text { High sensitivity } \\
\text { and simple } \\
\text { reaction system, } \\
\text { signal } \\
\text { amplification }\end{array}$ & $\begin{array}{l}\text { signal fluctuation } \\
\text { and hook effect }\end{array}$ \\
\hline $\begin{array}{l}\text { Micro-Nuclear Magnetic } \\
\text { Resonance ( } \mu \text { NMR) } \\
{[150,151]}\end{array}$ & $\begin{array}{l}\text { Immunomagnetic } \\
\text { nanoparticles binding } \\
\text { to EV surface antigen } \\
\text { induces magnetic field } \\
\text { change }\end{array}$ & $\begin{array}{l}\text { Magnetic } \\
\text { susceptibility }\end{array}$ & 1 & $10^{7}$ & yes & $\begin{array}{l}\text { Simple } \\
\text { operation }\end{array}$ & $\begin{array}{l}\text { require special } \\
\text { instrument }\end{array}$ \\
\hline
\end{tabular}

takes less than $1 \mathrm{~h}$. In this study, the detection limitation of the chip can go down to $3.3 \times 10^{9}$ particles/mL. The advantage of this method is short and easy protocol, and can also be applied to primary screening in clinical setting. However, this method still cannot eliminate the contamination of lipid protein.

intravesicular nano-plasmonic system (iNPS) Currently, most detection methods are limited to exosome surface protein, but this EV screening assay [160] can in advance detect both intravesicular (AKT1) and transmembrane protein (EpCAM, CD63) of exosome via lysis. This system relies on nanohole-based surface plasmon resonance (SPR) technique. The chip is formed nanoholes with a diameter of $200 \mathrm{~nm}$ in a thin $(100 \mathrm{~nm})$ golden film. The chip surface is coated with specific antibody as ELISA, and an obvious signal shift will be detected once the double antibody sandwich (antibodyprotein-antibody-AuNPs) forms. In this platform, only $0.5 \mu \mathrm{L}$ of sample is required for each marker, almost 200 -fold volume of sample less than of ELISA.

Raman tweezers microspectroscopy (RTM) RTM has been used to characterize exosome chemical composition (relative amount of nucleic acids, lipids and proteins) via Raman fingerprints, which could be completed in several seconds or minutes without any label. Zachary et al. [161] used the optical tweezer method and found that spectral variation may origin from cholesterol and protein expression in exosome surface. Moreover, Ire'ne et al. [162] attempted to detect human urine exosomes by RTM. It should be noted that the exosomes in this study needed to be purified from urine. Randy et al. [163] combined multispectral optical tweezers (MSOTs) and fluorescence antibody labeling to make Raman spectra measurement of $\mathrm{CD} 9(+)$ exosome subpopulations. The labeled and fluorescent exosomes were trapped with $785 \mathrm{~nm}$ optical tweezers. Compared with other more informative methods such as proteomics, genomics, optical tweezers combined with Raman spectroscopy technique may not provide comprehensive data on protein and nucleic acids in exosomes, but it can serve as complementary technique for those other timeconsuming method. In summary, it is a promising alternative method for rapid exosome characterization.

\section{Aptamer-based methods}

It has been widely known that the antibody can be employed as capture tool for exosomes isolation. However, recent reports suggested that the single-stranded oligonucleotides possess similar binding affinity with specificity for associated molecules on the exosome membrane. 
Table 5 Comparison of antibody-based analysis technology for analyzing exosome proteins

\begin{tabular}{|c|c|c|c|c|c|c|c|c|}
\hline Method & Basic principle & $\begin{array}{l}\text { Signal } \\
\text { output }\end{array}$ & $\begin{array}{l}\text { Sample } \\
\text { volume } \\
(\mu \mathrm{L})\end{array}$ & $\begin{array}{l}\text { LOD } \\
\text { (particles/ } \\
\mathrm{mL} \text { ) }\end{array}$ & $\begin{array}{l}\text { Dynamic } \\
\text { range }\end{array}$ & $\begin{array}{l}\text { Analysis } \\
\text { time }\end{array}$ & Advantages & Disadvantages \\
\hline $\begin{array}{l}\text { iKEA (integrated } \\
\text { kidney exosome } \\
\text { analysis) [152] }\end{array}$ & $\begin{array}{l}\text { Combination of } \\
\text { MAIA (Magnetic } \\
\text { antibody } \\
\text { immunization assay) } \\
\text { and chip technique }\end{array}$ & $\begin{array}{l}\text { Electrical } \\
\text { currents }\end{array}$ & $\begin{array}{l}0-15 \\
000\end{array}$ & $1.6 \times 10^{4}$ & $10^{4}$ & $2 \mathrm{~h}$ & $\begin{array}{l}\text { detection signal in } \\
\text { this platform can be } \\
\text { wirelessly transferred } \\
\text { to Bluetooth-ready } \\
\text { devices }\end{array}$ & $\begin{array}{l}\text { The exosome } \\
\text { needs to be } \\
\text { purified in } \\
\text { advance }\end{array}$ \\
\hline ExoPCD-chip [153] & $\begin{array}{l}\text { CD63 (an enriched } \\
\text { marker in exosomes } \\
\text { surface) aptamer26 } \\
\text { and hemin/LGCD } \\
\text { (formed by mimicking } \\
\text { DNAzyme sequence } \\
\text { and CD63 aptamer) } \\
\text { trigger redox reaction } \\
\text { of NADP; a Microfluidic } \\
\text { technique based on } \\
\text { immune magnetic } \\
\text { bead. }\end{array}$ & absorbance & 30 & $4.39 \times 10^{3}$ & $10^{5}$ & $3.5 \mathrm{~h}$ & $\begin{array}{l}\text { without purification } \\
\text { in advance }\end{array}$ & $\begin{array}{l}\text { The reaction } \\
\text { system is } \\
\text { complex and } \\
\text { the detection } \\
\text { process takes a } \\
\text { long time }\end{array}$ \\
\hline $\begin{array}{l}\text { ZnO nanowires } \\
\text { coated three- } \\
\text { dimensional (3D) } \\
\text { scaffold chip [154] }\end{array}$ & $\begin{array}{l}\text { utilize } \mathrm{ZnO} \text { nanowires } \\
\text { immobilized with } \\
\text { exosome-specific } \\
\text { antibody to isolate } \\
\text { exosome, and } \\
\text { colorimetric assay } \\
\text { (HRP catalyze } \mathrm{H}_{2} \mathrm{O}_{2-}^{-} \\
\text {mediated oxidation } \\
\text { of TMB) for exosome } \\
\text { detection. }\end{array}$ & absorbance & 100 & $2.2 \times 10^{4}$ & $10^{3}$ & - & $\begin{array}{l}\text { The qualitative result } \\
\text { can be observed by } \\
\text { naked eyes. Chip is } \\
\text { small and without } \\
\text { special instrument } \\
\text { for result reading. } \\
\text { Separated exosomes } \\
\text { can be released again }\end{array}$ & $\begin{array}{l}\text { Serum and } \\
\text { plasma serum } \\
\text { or plasma need } \\
\text { to be pumped } \\
\text { rather than } \\
\text { directly added } \\
\text { to. }\end{array}$ \\
\hline $\begin{array}{l}\text { PDA encapsulated } \\
\text { antibody-reporter- } \\
\text { Ag (shell)-Au (core) } \\
\text { multilayer (PEARL) } \\
\text { SERS tags chip [155] }\end{array}$ & $\begin{array}{l}\text { polydopamine- } \\
\text { modified } \\
\text { immunocapture } \\
\text { substrates and an } \\
\text { ultrathin polydopamine- } \\
\text { encapsulated antibody- } \\
\text { reporter-Ag (shell)-Au } \\
\text { (core) multilayer (PEARL) } \\
\text { Surface-Enhanced } \\
\text { Raman Scattering } \\
\text { (SERS) nano-tag with } \\
\text { quantitative signal of } \\
\text { the Raman reporter } \\
\text { at } 1072 \mathrm{~cm}^{-1} \text { : a sandwich } \\
\text { immunoassay }\end{array}$ & $\begin{array}{l}\text { Raman intensity } \\
\text { at } 1072 \mathrm{~cm}^{-1}\end{array}$ & 2 & $\begin{array}{l}5.418 \times \\
10^{2}\end{array}$ & $10^{3}$ & $3 \mathrm{~h}$ & $\begin{array}{l}\text { ultra-smallsample } \\
\text { volume, high } \\
\text { sensitivity. }\end{array}$ & $\begin{array}{l}\text { Experimental } \\
\text { materials are } \\
\text { complex and } \\
\text { expensive to } \\
\text { construct }\end{array}$ \\
\hline ExoCounter [156] & $\begin{array}{l}\text { The sandwich structure } \\
\text { (Ab-exosome-Ab- } \\
\text { conjugated single FG } \\
\text { bead) on a removal } \\
\text { plate } \\
\text { Containing } 16 \text { wells } \\
\text { on DVD is detected } \\
\text { by a photodetector } \\
\text { to achieve specific } \\
\text { exosome quantification } \\
\text { at the removal of } \\
\text { optical disc drive. }\end{array}$ & relative voltage & 0.39 & about $10^{6}$ & $10^{3}$ & $2.5 \mathrm{~h}$ & $\begin{array}{l}\text { Label-free, without } \\
\text { pretreatment, higher } \\
\text { sensitivity than flow } \\
\text { cytometry }\end{array}$ & $\begin{array}{l}\text { Limited by } \\
\text { antibody } \\
\text { binding force, } \\
\text { some } \\
\text { exosomes may } \\
\text { be missed }\end{array}$ \\
\hline $\begin{array}{l}\text { Electrochemical } \\
\text { assays [157] }\end{array}$ & $\begin{array}{l}\text { Combination of a } \\
\text { sandwich immune } \\
\text { assay and } \\
\text { electrochemistry } \\
\text { detection }\end{array}$ & current signal & 5 & $4.7 \times 10^{8}$ & not offer & $2 \mathrm{~h}$ & $\begin{array}{l}\text { Cost-effective, } \\
\text { require tedious } \\
\text { electrode surface } \\
\text { functionalization. }\end{array}$ & $\begin{array}{l}\text { Reproducibility } \\
\text { is not good } \\
\text { and sensitivity } \\
\text { is low }\end{array}$ \\
\hline
\end{tabular}


Multiple detection of exosomes using magnetic substrates and SERS probes Surface enhanced Raman spectroscopy (SERS) is a technique derived from Raman spectroscopy. Raman spectroscopy is an optical technique that is based on detection of inelastic scattered light when a particle is illuminated by monochromatic laser light. The energy transportation related to molecular vibration will induce a wavelength shift, which can served as a specific footprint for different molecules [164, 165]. Raman spectrum can be used for exosome size measurement or quantification as well [166]. Since trapping process in Raman spectroscopy analysis is a random process, overlong measurement time strongly hinders its application [167]. Meanwhile, the too subtle signal from exosome become another obstruction. So here comes the SERS technique. Raman signal can be strongly enhanced in SERS (up to $10^{14-15}$ times). It is based on plasmon excitation on irregular metal surfaces, usually, Au or Ag. SERS can serve as a valuable tool to discriminate exosome subpopulations [168, 169]. SERS technology has been widely used in ultrasensitive detection of exosomes, whether quantification or characterization [155, 170]. This method uses magnetic substrate and SERS (surface enhanced Raman scattering) probe to detect multiply exosomes. As principle is shown in Fig. 8, firstly, universal surface protein CD63 aptamer-modified gold shell magnetic nanoparticles are used for exosomes capture. Three gold nanoparticles, as probes, are respectively modified with aptamers (CEA for colon cancer, $\mathrm{H} 2$ for breast cancer, PSMA for prostate cancer) targeted specific exosomes and three Raman reporters (DTNB, MMC, and 2NAT) are then simultaneously added into above magnetic complex. With the formation of golden particle-positive exosome-magnetic beads complex, the decreased Raman signal peak is detected in the supernatant after magnet separation, showing the

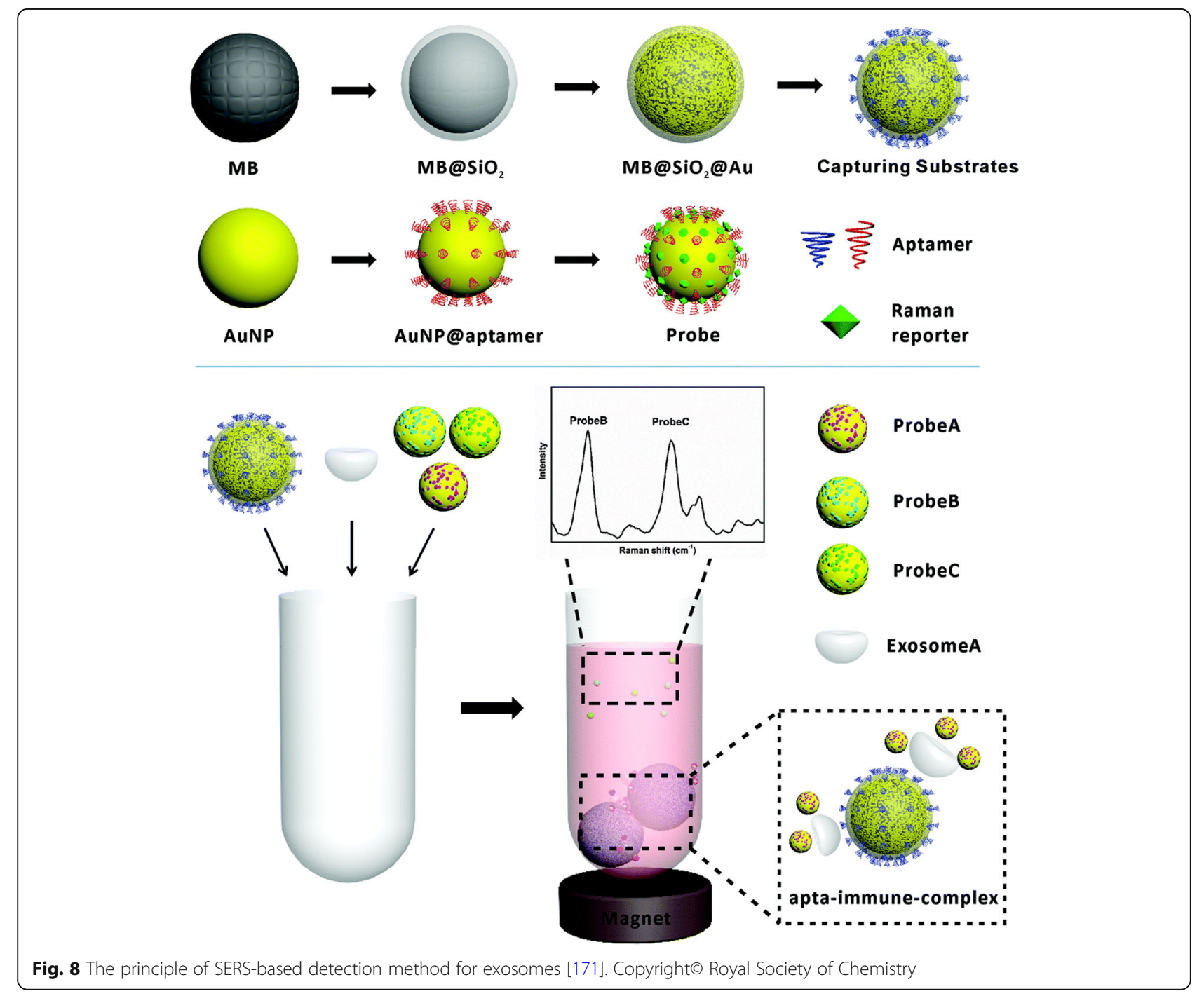


presence of cancer-specific exosome. For exosomes from SKBR3 cell (breast cancer cell), the LOD values can reach down to 32 exosomes per microliter and dynamic range can reach four magnitude [171].

Aptamer/AuNP biosensor for colorimetric profiling of exosomal proteins This method [172] involves visual detection of exosome surface protein. This platform utilized aptamer on AuNP and protected its aggregation in high-salt solution. But when special exosome appears in the sample, stronger binding between aptamer and exosome separates the aptamer from AuNP, forming visual deposit. The principle is shown in Fig. 9. The method achieves profiling via a panel of aptamer/protein interactions successively, not protein scanning in the true sense.

SOMAmers platform SOMAmers (Slow Off-rate Modified Aptamers), sometimes referenced as SOMAscan Array, is formed with high affinity $\left(10^{-9}\right.$ to $\left.10^{-12} \mathrm{M}\right)$ and high specificity chemically modified aptamer to target protein. With multiple aptamers assembling in a small platform, this device can precisely measure more than 1100 proteins, but has the same performance as sandwich ELISA in sensitivity (LOD $40 \mathrm{fM}$ ). This technique has been engaged in discovery of cancer associated marker protein [173]. Jason et al. [174] utilized SOMAs$\operatorname{can}^{\mathrm{Tm}}$ array (version 3.0) to detect Du145 prostate cancer cell line derived exosome protein profiling. They found more than 300 unknown exosome protein previously, suggesting SOMAmers based technique is an effective weapon for exosome protein profiling. Moreover, this technique is also used for serum, plasm, tissue lysis and cerebrospinal fluid $[175,176]$. However, for most other antibody-based platforms, arrays are limited to less than 100 , with the interference of second antibody to reaction specificity, making them not very efficient compared to SOMAmers platform [177].

\section{Proteomics analysis with mass-spectrometry (MS)}

Proteomics analysis of exosomes was firstly applied to dendritic cells derived exosomes in 2001 [178]. Early MS can only detect high-abundance exosome protein. The MS technique can provide complete information about protein profile of exosome, which is more likely to find new biomarkers for disease diagnosis and other functional proteins. To date, more than 1000 exosome proteins in urine were identified via MS [179] Generally speaking, there are two paths that can be used to analyze exo-protein: one involves removal of surface protein with maintenance of intact structure of exosomes, and the other uses lysis agent to disrupt the whole spatial configuration of exosome, causing total protein

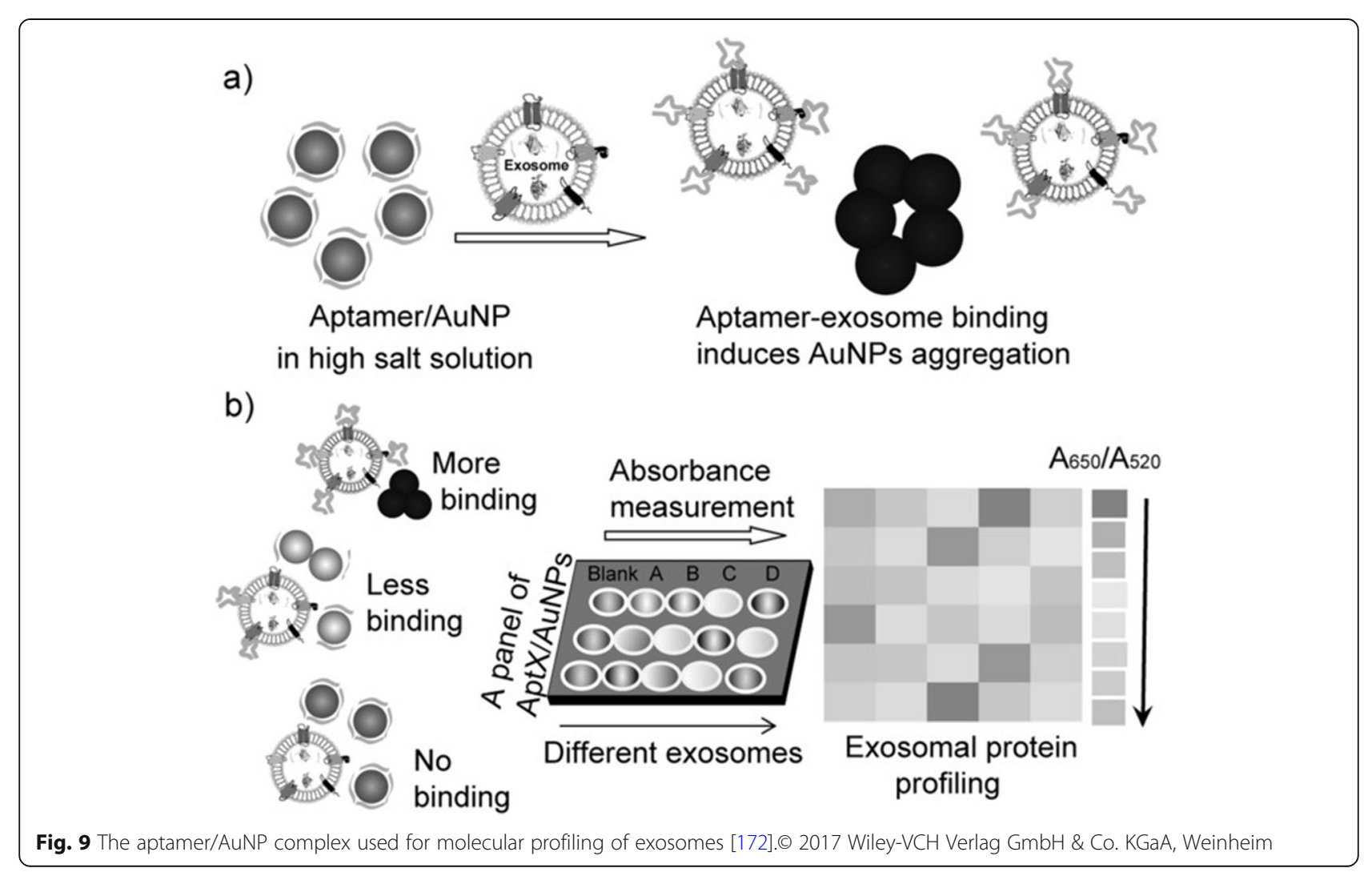


distribution in the solution. The shaving of exosome surface protein need to remove post-translational modifications, purify protein by filter-aided sample preparation (FASP) method with artificially added enzyme and other agents [110] like trypsin [180]. A review [181] paper has summarized the present methodological approaches for high-throughput mass spectrometry-based proteomic analyses of exosomes. SBI company has developed the XPEP kit to cleave away of protein from exosome surface. Of course, the peptide library obtained from exosome total lysis stand more for protein composition and contribute to biomarkers discovery of inner protein, considering the fact that surface protein only take in $20 \%$ of the total protein content [110]. Current standard instruments for exo-protein analysis conclude nano LC/ MS/MS Q Exactive of Thermo Fisher with Waters Nano Acquity HPLC system, while sequent peptide identities need to be mapped to Mascot databases. There are several points that need to be remembered in mind: The MS for protein analysis has strong randomness since there is a step for enzyme digestion. Sometimes, owing to its high sensitivity, the specificity from MS is correspondingly decreased. Despite use of cell line medium, clinical serum, or dedicated bioreactors, the soluble protein released by cells in MS is very hard to eliminate, making high requirements for exosome purity preparation [182-184], making the already complex steps more cumbersome. And considering its low repeatability, the method is not suitable for clinical application. As for data analysis, the group and classification of detected proteins should be compared with an authoritative database like Vesiclepedia [185], Exocarta, EV pedia [186].

\section{Exosome nucleic acid detection}

Emerging reports have asserted exosome indispensable function in intercellular communication, as exosome RNA has key role among all exosome cardo. Figure 10 shows RNA types in exosome of various origins [110]. The potential of exosomal RNA in clinical diagnosis and therapy warrants application of more advanced techniques for exosomal RNA analysis and RNA composition comparison between the cancer-derived exosome and normal exosome.

After purifying exosomes from plasma or cell culture supernatants via suitable isolated method, RNA can then be extracted by purification kits, such as SBI's SeraMir kit, mirRCURY RNA Isolation Kit (Exiqon, Vedbaek, Denmark) [187], Exosome Total RNA Extraction Kit (HansaBioMed), phenolisopropanol precipitation (Trizol, Invitrogen) or Exosome RNA Isolation Kit (Norgen Biotek). However, the isolation methods for exosome will actually affect RNA measurements to a certain extent [188]. If the blood sample comes from the heparin anticoagulant tube, it is recommended to treat the plasma

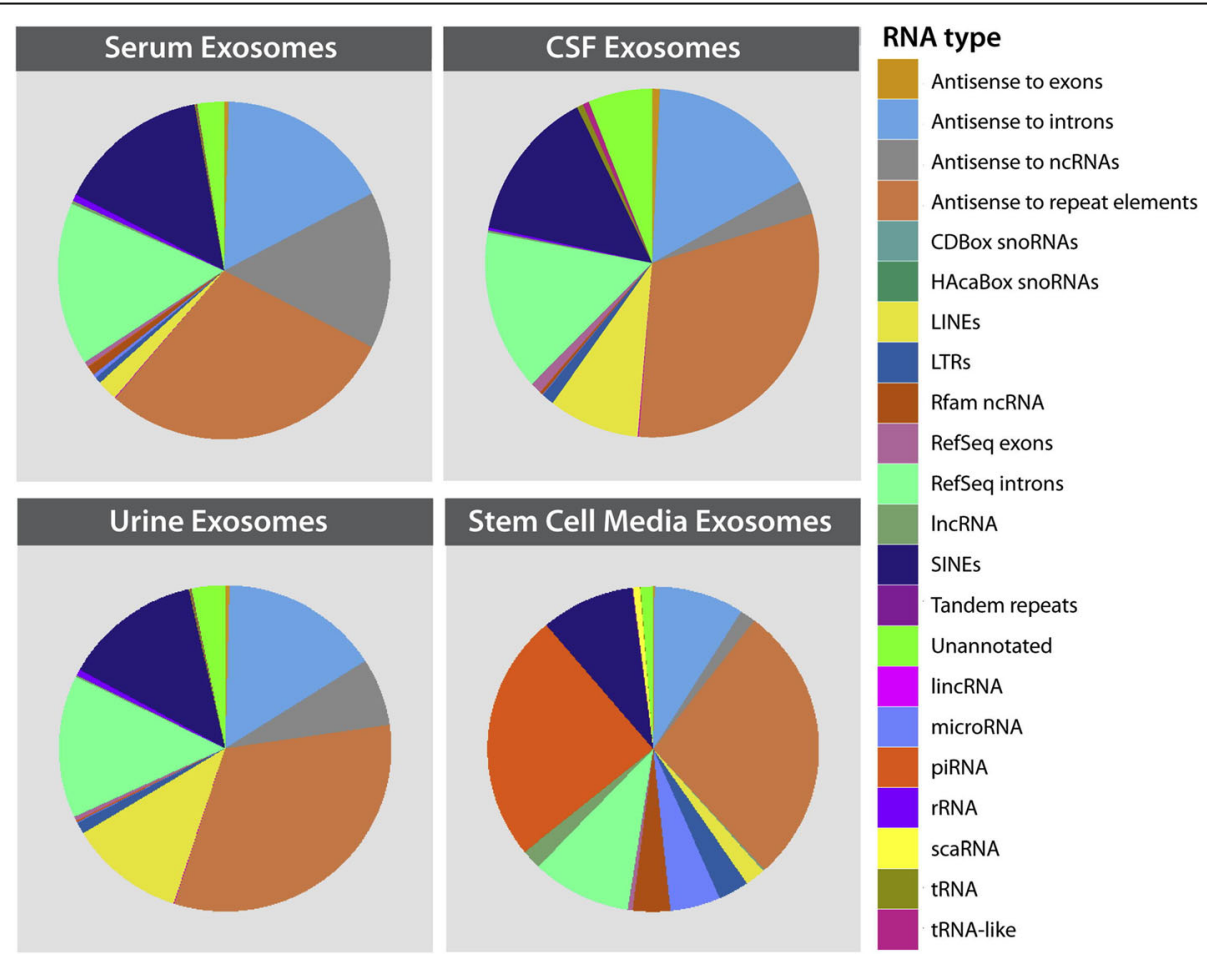

Fig. 10 The abundances and types of specific RNA classes present in exosome by NGS sequence [110]. Copyright@ 2015 Elsevier Inc. All rights reserved 
with heparin enzymes to prevent potential interference in subsequent reverse transcription experiment [110].

RNA qualitative analysis can be operated on spectrophotometer (Nanodrop Technologies). Since there is limited level and size of exosomal RNA compared to the complete cell, Agilent 2100 Bioanalyzer instrument is more recommended for higher accuracy and sensitivity to characterize RNA quality and concentration. The analysis process is operated on the chip and processed by software. After the complement of exosomal RNA quality and quantity estimation, RNA can be amplified to cDNA by QuantiTect Reverse Transcription kit (Qiagen) or SBI SeraMir Kit. Expression analysis of RNA in exosome of different sources can then be estimated by quantitative realtime (RT-qPCR), and microarray can be utilized as well. Moreover, next-generation sequencing can characterize whole transcriptome contained in exosomes, making it a powerful weapon for the current study of exosomal nucleic acids. Although blind as it may seem, this method can effectively help find novel significant sequence. The library preparation protocol mainly contains adapter ligation, cDNA synthesis, and PCR amplification. At the PCR amplification step, each RNA sequence is marked with a specific index primer and index (bar codes) which allows parallel sequencing in a flow cell along with other samples indexed with different sequences simultaneously. Amplified RNA libraries are then separated by run in a polyacrylamide gel electrophoresis. The amplified libraries can be analyzed on the Illumina sequencing platforms: HiSeq, MiSeq, and Genome Analyzer [110]. PCR-free efficient diagnosis methods are mostly probe-based, and mainly include microarray and molecular beacon. The microarray can recognize specific RNA sequence though the hybridization with more than 1000 Nucleic acid probe single distributed on microarray chip. Current RNA profiling chip mainly concludes Affymetrix Gene Chip miRNA Array 1.0 [189]. But this technology is not suitable for discovery of new RNA sequences and has an inferior transcript quantification ability compared to next-generation sequencing [189]. Molecular beacon $(\mathrm{MB})$ is fluorescently labeled oligonucleotide chain with hairpin structure. Once the MB is bound with its complementary sequence, a strong fluorescence signal will be observed. It has been used in the detection of tubercle bacillus resistance genes as early as 20 years ago. It has also been used in the recent 5 years to identify mRNAs and microRNAs in exosome of lung cancer [190, 191], breast cancer [181, 192], pancreatic cancer [193], and prostate cancer. Only when beacons penetrate into exosome can they hybridize with targeted RNA. Making membrane permeabilization with streptolysin O (SLO) [191] or relying on MB's own penetration [194] are both feasible.

Exosomal target miR-21 MB can directly penetrate into exosomes without need for saponin treatment [190]. Moreover the MB-based fluorescence detection technology has been able to accomplished simultaneous and multiple detection of miRNA inside the exosome from the serum of a high concentration $(70 \% \mathrm{v} / \mathrm{v})$ [190] or urine of $60 \%(\mathrm{v} / \mathrm{v})$ [195], without need for exosome isolation or RNA extraction. The methodology of this technology is relatively mature, and the detail experiment process has been reported [194].

The DNA content in exosome is quite rare compared to RNA. Most methods in RNA analysis, like nextgeneration DNA sequencing, real time quantitative PCR, micro array etc. can be also used for DNA content detection in exosomes.

\section{Exosome lipid detection}

Lipidology analysis techniques at cellular level have been developed maturely, and related review herein discusses different MS analyses in qualification and reproducibility aspects that have been published [196-198]. There are very few reports that concentrate on exosome lipid analyses methodology evaluation and innovation. This may be because of the relatively not rich biological function of exosome lipid. In the past decade, techniques including layer chromatography (TLC), gas liquid chromatography (GLC) and mass spectrometry (MS) have been mostly reported [199]. LC-MS based platform named micro LC QTOF MS has been demonstrated for urinary exosomes lipidology study [200]. High-throughput screening MSbased approach like ESI-MS (electrospray ionization-mass spectrometry) and MALDI-TOF (matrix-assisted laser desorption ionization-time of flight) have attracted more attention in the science community owing to their high efficiency and sensitivity for sample detection.

\section{Exosome glycan detection}

There are more complex structures of macromolecules and relatively less various biological function of glycans, hence diverse and specific methods need to be developed. In brief, for general characterization of glycosylation, lectins are often employed at present. Lectins are proteins that bind to specific glycan structures. The lectins involved in glycosylation analysis technique contain blots [201], lectin arrays and lectin affinity purification.

\section{Conclusion and future perspective}

Exosomes are small vesicles widely distributed in human body fluids. They are gradually and extensively accepted by the whole science community, in terms of their function in transferring biological molecules between cells, as well as their potential to become biomarkers for a series of diseases. Increasing studies have shown that exosomes play a key role in physiological or pathological processes, which also provides a theoretical basis for their use as a novel diagnostic tool. Various separation or detection methods are constantly being introduced at 
a booming speed. However, there is still a long way to go before exosomes become a routine testing item in tumor diagnosis.

The establishment of standardized purification and detection method and discovery of exosomeassociated tumor markers The standard protocols for isolation and detection of exosomes are suitable for clinical applications, however, there are still major limitations to their clinical application. An ideal clinical method for detection of exosomes need to have the characteristics of high-throughput, short timeconsumption, operability, high sensitivity, specificity, and results should be stable even at the interference of other biological substances, such as lipoprotein, apoptotic bodies and other extracellular vesicles. As summarized in Tables 1 and 2, there are many exosomal biomarkers that have come to light. However, owing to the lack of standard analysis method, many statistics are not comparable. Moreover, results from these small sample sized experiments are unconvincing when used to establish cut-off value or not to say evaluating diagnostic performance of every biomarker. Standardized research methods for exosomes should therefore be established as soon as possible, and novel biomarkers discovery should not be forgotten. At present, most protein biomarkers research is limited on membrane surface protein, while protein markers in exosome remain as a virgin land. Proteomics analysis will therefore contribute a lot in inner protein marker discovery.

Single exosome detection is of great significance Cells secrete more than one kind of exosome, which lead to high heterogeneity in exosomes [202, 203], and it's well known that exosome compositions change with changing physiological state of parent cell. The detection of the whole exosome population cannot meet the needs for exploring the nature of the disease. Single exosome detection is always the future development direction. Meanwhile, numerous normal cells continuously release exosome, making it is very challenging to isolate and analyze the tumor-derived exosomes in such huge population. Most methods provide an average characteristic based on the whole exosome population detection, inducing information from tumor-derive exosome that may be submerged in signal pool, which is mainly consisted of the normal particles. It is not difficult to speculate that total exosome qualitative detection may never reach the goal of dynamic monitor of tumor progression as original intention of liquid biopsy. If one wants to apply exosome technology in clinical diagnosis as soon as possible, you must focus on the detection of tumor-derived exosomes subpopulation, and find more specific markers for tumor exosomes, by trying to eliminate interference from normal exosomes as much as possible. Optical tweezer technique may become a key for such problem, since it can trap only several exosomes in a light with certain wavelength. There are scientists [163] attempting to make measurement of exosome subpopulation via this method.

Aptamer will play a more vital role in exosome detection Exosomes can be purified before being tested to overcome the shortcomings of ordinary nucleic acid aptamers (without any modification) that are easily degraded or neutralized by related proteins in body fluids. And aptamer may own better prospect than antibodybased immune detection in realistic utilization, because: 1. Aptamers have both function of specific recognition and PCR/HCR (Hybridization Chain Reaction) based signal amplification. Nucleic acid amplification technology has rapidly developed, and the present used methods account for a small part in aptamer-based methods. 2. The weaker binding compared to antibodies makes aptamers very easy for exosome elution, with less impairment on exosome morphology and function. So, it is more conducive to use aptamers in researching on biological function of exosomes. 3. The aptamer targeted tumor exosome selective technique is similar to CELL-SELEX, and will help to find a new way for discovery of specific biomarkers except for complex MS. Moreover, the stability of heat and well-established synthesis, modifications and high-sensitivity analysis technologies, also make aptamers as perfect agents for exosome detection.

Microfluidic technology is more suitable for the analysis of exosomes The microfluidic method is the breaking point of exosomes testing in future clinical application. With low requirement for sample volume, the microfluidic method can achieve the goal of minimizing the size, cost, complexity of detection, accomplishing the whole reaction more quickly, and most of all, performing various experiments in a tiny space at the same time.

As mentioned above, growing number of researchers are moving ahead on this road, and there have been researchers who have designed microfluidic chips for immunocapture, by effectively combining the advantages of immunomagnetic beads and microfluidics chip. Even primitive as it may seem, it can stand for development orientation for future research, and above all, the beadexosome complexes can be combined with characterization techniques, such as flow cytometry, electron microscopy, allowing qualitative detection during the process of isolation, and thus further saving examination time. Furthermore, how to connect multiple reactions seamlessly in a very small chip in a completely automatic manner remain to be a problem for follow-up researchers to think about. Lastly, the 
development of a perfect exosome detection instrument is inseparable from deep cooperation between engineers, clinicians, chemists and physicists. We believe that with continuous improvement of microfluidic technology, exosomes in clinical large-scale application will come to patient's bed soon.

\section{Acknowledgments}

This work was supported by the National Key Research and Development Program of China (2017YFA0205301), National Natural Scientific Foundation of China (61971216), the Jiangsu Province Medical Talent (ZDRCA2016065), the Key Research and Development Project of Jiangsu Province (BE2019603), the High-level Health Talent Project of Jingsu Procince (LGY2019001).

\section{Conflict of interest}

The authors declare that they have no conflict of interest.

\section{Authors' contributions}

Mengjiao S, Kaili D were major contributor in writing the manuscript. Yanyan X, Hui X, Rongrong H, Chang L, Yang M, Siyang Z, Nongyue $H$, Zhiyang $L$ modified this review and made suggestions. All authors read and approved the final manuscript.

\section{Funding}

This work was supported by the National Key Research and Development Program of China (2017YFA0205301), National Natural Scientific Foundation of China (61971216), the Jiangsu Province Medical Talent (ZDRCA2016065), the Key Research and Development Project of Jiangsu Province (BE2019603), the High-level Health Talent Project of Jingsu Procince (LGY2019001). Postdoctoral Science Foundation of Jiangsu Province (2020Z399), Policy Research Project of Shanghai Municipal Health Commission (2020HP03).

\section{Availability of data and materials}

Not applicable.

\section{Ethics approval and consent to participate}

Not applicable.

\section{Consent for publication}

Not applicable.

\section{Competing interests}

The authors declare that they have no competing interests.

\section{Author details}

${ }^{1}$ Department of Clinical Laboratory, the Affiliated Drum Tower Hospital of Nanjing University Medical School, Nanjing 210008, China. ${ }^{2}$ Shanghai Health Development Research Center, Shanghai, China. ${ }^{3}$ Captis Diagnostics Inc, Pittsburgh, PA 15213, USA. ${ }^{4}$ Department of Biomedical Engineering, the Hong Kong Polytechnic University, Hunghom, Kowloon, Hong Kong, People's Republic of China. ${ }^{5}$ Department of Biomedical Engineering and Electrical \& Computer Engineering, Carnegie Mellon University, 5000 Forbes Avenue, Scott Hall 4N211, Pittsburgh, PA 15213, USA. '5tate Key Laboratory of Bioelectronics, School of Biological Science and Medical Engineering, Southeast University, Nanjing 210096, China.

Received: 29 June 2020 Accepted: 15 July 2020

Published online: 14 August 2020

\section{References}

1. Kalluri R, LeBleu VS. The biology, function, and biomedical applications of exosomes. Science. 2020;367(6478):eaau6977.

2. Huang-Doran I, Zhang C-Y, Vidal-Puig A. Extracellular vesicles: novel mediators of cell communication in metabolic disease. Trends Endocrinol Metab. 2017;28(1):3-18.

3. Théry C, Zitvogel L, Amigorena S. Exosomes: composition, biogenesis and function. Nat Rev Immunol. 2002;2(8):569-79.

4. Mitchell PJ, Welton J, Staffurth J, Court J, Mason MD, Tabi Z, et al. Can urinary exosomes act as treatment response markers in prostate cancer? J Transl Med. 2009;7(1):4.
5. Taylor DD, Gercel-Taylor C. MicroRNA signatures of tumor-derived exosomes as diagnostic biomarkers of ovarian cancer. Gynecol Oncol. 2008;110(1):13-21.

6. Rosell R, Wei J, Taron M. Circulating MicroRNA signatures of tumor-derived exosomes for early diagnosis of non-small-cell lung cancer. Clin Lung Cancer. 2009;10(1):8-9.

7. Riches A, Campbell E, Borger E, Powis S. Regulation of exosome release from mammary epithelial and breast cancer cells - a new regulatory pathway. Eur J Cancer. 2014;50(5):1025-34.

8. Mariantonia L, Angelo DM, Luana L, Martina B, Luana C, Massimo S, et al. High levels of exosomes expressing CD63 and caveolin-1 in plasma of melanoma patients. PLoS One. 2009;4(4):e5219.

9. Liu Q, Xiang Y, Yuan S, Xie W, Li C, Hu Z, et al. Plasma exosome levels in non-small-cell lung cancer: Correlation with clinicopathological features and prognostic implications. Cancer Biomark A Dis Markers. 2018;22(2):267-74.

10. Matsumoto $Y$, Kano M, Akutsu Y, Hanari N, Hoshino I, Murakami K, et al. Quantification of plasma exosome is a potential prognostic marker for esophageal squamous cell carcinoma. Oncol Rep. 2016;36(5):2535-43.

11. Sun B, Li Y, Zhou Y, Ng TK, Zhao C, Gan Q, et al. Circulating exosomal CPNE3 as a diagnostic and prognostic biomarker for colorectal cancer. J Cell Physiol. 2018.

12. Tian Y, Ma L, Gong M, Su G, Zhu S, Zhang W, et al. Protein profiling and sizing of extracellular vesicles from colorectal cancer patients via flow cytometry. ACS Nano. 2018;12(1):671-80.

13. Weber $C$. Biomarkers: the challenge to find biomarkers for the early detection of pancreatic cancer. Nat Rev Gastroenterol Hepatol. 2015;12(8):427.

14. Melo SA, Luecke LB, Kahlert C, Fernandez AF, Gammon ST, Lebleu VS, et al. Glypican-1 identifies cancer exosomes and detects early pancreatic cancer. Nature. 2015;523(7559):177-82

15. Baran J, Bajkrzyworzeka M, Weglarczyk K, Szatanek R, Zembala M, Barbasz J, et al. Circulating tumour-derived microvesicles in plasma of gastric cancer patients. Cancer Immunol Immunother. 2010;59(6):841.

16. Fu $H$, Yang $H$, Zhang $X$. Exosomal TRIM3 is a novel marker and therapy target for gastric cancer. J Exp Clin Cancer Res. 2018;37(1):162.

17. Mizutani K, Terazawa R, Kameyama K, Kato T, Horie K, Tsuchiya T, et al. Isolation of prostate cancer-related exosomes. Anticancer Res. 2014;34(7):3419.

18. Zhu J. Exosomal ephrinA2 derived from serum as a potential biomarker for prostate cancer. J Cancer. 2018;9(15):2659-65.

19. Khan S, Jutzy JMS, Valenzuela MMA, Turay D, Aspe JR, Ashok A, et al. Plasma-derived exosomal survivin, a plausible biomarker for early detection of prostate cancer. PLoS One. 2012;7(10):e46737.

20. Peinado H, Alečković M, Lavotshkin S, Matei I, Costasilva B, Morenobueno G, et al. Melanoma exosomes educate bone marrow progenitor cells toward a pro-metastatic phenotype through MET. Nat Med. 2012;18(6):883.

21. Logozzi M, De Milito A, Lugini L, Borghi M, Calabro L, Spada M, et al. High levels of exosomes expressing CD63 and caveolin-1 in plasma of melanoma patients. PLoS One. 2009:4(4):e5219.

22. Raimondo F, Morosi L, Corbetta S, Chinello C, Brambilla P, Della MP, et al. Differential protein profiling of renal cell carcinoma urinary exosomes. Mol BioSyst. 2013:9(6):1220-33.

23. Clark DJ, Fondrie WE, Yang A, Mao L. Triple SILAC quantitative proteomic analysis reveals differential abundance of cell signaling proteins between normal and lung cancer-derived exosomes. J Proteome. 2016:133:161-9.

24. Sandfeldpaulsen B, Jakobsen KR, Bæk R, Folkersen BH, Rasmussen TR, Meldgaard $\mathrm{P}$, et al. Exosomal proteins as a diagnostic biomarkers in lung cancer. J Thorac Oncol. 2016;11(10):1701-10.

25. Sandfeld-Paulsen B, Jakobsen KR, Bæk R, Folkersen BH, Rasmussen TR, Meldgaard $P$, et al. Exosomal proteins as diagnostic biomarkers in lung cancer. J Thorac Oncol. 2016;11(10):S1556086416305172.

26. Melo SA, Luecke LB, Christoph K, Fernandez AF, Gammon ST, Judith K, et al. Glypican-1 identifies cancer exosomes and detects early pancreatic cancer. Nature. 2015;523(7559):177-82

27. Khan S, Bennit HF, Turay D, Perez M, Mirshahidi S, Yuan Y, et al. Early diagnostic value of survivin and its alternative splice variants in breast cancer. BMC Cancer. 2014;14(1):176

28. Fu $H$, Yang $H$, Zhang $X$, Wang $B$, Mao J, Li $X$, et al. Exosomal TRIM3 is a novel marker and therapy target for gastric cancer. J Exp Clin Cancer Res. 2018;37(1):162

29. Moreno-Gonzalo O, Fernandez-Delgado I, Sanchez-Madrid F. Posttranslational add-ons mark the path in exosomal protein sorting. Cell Mol Life Sci. 2018;75(1):1-19. 
30. van Dommelen SM, Van der Meel R, van Solinge WW, Coimbra M, Vader $P$, Schiffelers RM. Cetuximab treatment alters the content of extracellular vesicles released from tumor cells. Nanomedicine. 2016;11(8):881-90.

31. Chen $\mathrm{H}$, Xue L, Hsu CC, Paez JS, Pan L, Andaluz H, et al. Phosphoproteins in extracellular vesicles as candidate markers for breast cancer. Proc Natl Acad Sci U S A. 2017;114(12):3175.

32. Runz S, Keller S, Rupp C, Stoeck A, Issa Y, Koensgen D, et al. Malignant ascites-derived exosomes of ovarian carcinoma patients contain CD24 and EpCAM. Gynecol Oncol. 2007;107(3):563-71.

33. Hyungsoon I, Huilin S, II PY, Peterson VM, Castro CM, Ralph W, et al. Labelfree detection and molecular profiling of exosomes with a nano-plasmonic sensor. Nat Biotechnol. 2014;32(5):490-5.

34. Escrevente C, Grammel N, Kandzia S, Zeiser J, Tranfield EM, Conradt HS, et al. Sialoglycoproteins and N-Glycans from secreted exosomes of ovarian carcinoma cells. PLoS One. 2013:8(10):e78631.

35. Gomes J, Gomes-Alves P, Carvalho SB, Peixoto C, Alves PM, Altevogt P, et al, Extracellular vesicles from ovarian carcinoma cells display specific glycosignatures. Biomolecules. 2015;5(3):1741-61.

36. Chaiyawat $P$, Weeraphan $C$, Netsirisawan $P$, Chokchaichamnankit D, Srisomsap C, Svasti J, et al. Elevated O-GlcNAcylation of extracellular vesicle proteins derived from metastatic colorectal cancer cells. Cancer Genomics Proteomics. 2016;13(5):387.

37. Menck K, Scharf C, Bleckmann A, Dyck L, Rost U, Wenzel D, et al. Tumorderived microvesicles mediate human breast cancer invasion through differentially glycosylated EMMPRIN. J Mol Cell Biol. 2015;7(2):143-53.

38. Yokoi A, Villar-Prados A, Oliphint PA, Zhang J, Song X, De Hoff P, et al. Mechanisms of nuclear content loading to exosomes. Sci Adv. 2019;5(11): eaax8849-eaax.

39. Zhou W, Fong MY, Min Y, Somlo G, Liu L, Palomares MR, et al. Cancersecreted miR-105 destroys vascular endothelial barriers to promote metastasis. Cancer Cell. 2014;25(4):501-15.

40. García JM, Peña C, García V, Domínguez G, Muñoz C, Silva J, et al. Prognostic value of LISCH7 mRNA in plasma and tumor of colon cancer patients. Clin Cancer Res. 2007;13(21):6351-8.

41. Zhu L, Li J, Gong Y, Wu Q, Tan S, Sun D, et al. Exosomal tRNA-derived small RNA as a promising biomarker for cancer diagnosis. Mol Cancer. 2019: 18(1):74.

42. Wang L, Li Y, Guan X, Zhao J, Shen L, Liu J. Exosomal double-stranded DNA as a biomarker for the diagnosis and preoperative assessment of pheochromocytoma and paraganglioma. Mol Cancer. 2018;17(1):128.

43. Madhavan B, Yue S, Galli U, Rana S, Gross W, Müller M, et al. Combined evaluation of a panel of protein and miRNA serum-exosome biomarkers for pancreatic cancer diagnosis increases sensitivity and specificity. Int J Cancer. 2015;136(11):2616-27.

44. Que R, Ding G, Chen J, Cao L. Analysis of serum exosomal microRNAs and clinicopathologic features of patients with pancreatic adenocarcinoma. World J Surg Oncol. 2013;11(1):219.

45. Li J, Li Z, Jiang P, Peng M, Zhang X, Chen $K$, et al. Circular RNA IARS (circIARS) secreted by pancreatic cancer cells and located within exosomes regulates endothelial monolayer permeability to promote tumor metastasis. J Exp Clin Cancer Res. 2018;37(1):177.

46. Cazzoli R, Buttitta F, Di Nicola M, Malatesta S, Marchetti A, Rom WN, et al. microRNAs derived from circulating exosomes as noninvasive biomarkers for screening and diagnosing lung cancer. J Thorac Oncol. 2013;8(9):1156-62.

47. Rodríguez M, Silva J, Lópezalfonso A, Lópezmuñiz MB, Peña C, Domínguez $G$, et al. Different exosome cargo from plasma/bronchoalveolar lavage in non-small-cell lung cancer. Genes Chromosom Cancer. 2014;53(9):713-24.

48. Mao $X$, Sun $Y$, Tang J. Serum miR-21 is a diagnostic and prognostic marker of primary central nervous system lymphoma. Neurol Sci. 2014; 35(2):233-8

49. Manterola L, Guruceaga E, Gállego PJ, Gonzálezhuarriz M, Jauregui P, Tejada $\mathrm{S}$, et al. A small noncoding RNA signature found in exosomes of GBM patient serum as a diagnostic tool. Neuro-Oncology. 2014;16(4):520-7.

50. Srivastava A, Moxley K, Ruskin R, Dhanasekaran DN, Zhao YD, Ramesh R. A non-invasive liquid biopsy screening of urine-derived exosomes for miRNAs as biomarkers in endometrial cancer patients. AAPS J. 2018;20(5):82.

51. Zhou CF, Ma J, Huang L, Yi HY, Zhang YM, Wu XG, et al. Cervical squamous cell carcinoma-secreted exosomal miR-221-3p promotes lymphangiogenesis and lymphatic metastasis by targeting VASH1. Oncogene. 2018.

52. Zhan $Y$, Du L, Wang $L$, Jiang $X$, Zhang $S$, Li J, et al. Expression signatures of exosomal long non-coding RNAs in urine serve as novel non-invasive biomarkers for diagnosis and recurrence prediction of bladder cancer. Mol Cancer. 2018;17(1):142.

53. Zheng R, Du M, Wang X, Xu W, Liang J, Wang W, et al. Exosometransmitted long non-coding RNA PTENP1 suppresses bladder cancer progression. Mol Cancer. 2018;17(1):143.

54. Cho S-J, Yoon C, Lee JH, Chang KK, Lin J-X, Kim Y-H, et al. KMT2C mutations in diffuse-type gastric adenocarcinoma promote epithelial-to-mesenchymal transition. Clin Cancer Res. 2018.

55. Tang W, Fu K, Sun H, Rong D, Wang H, Cao H. CircRNA microarray profiling identifies a novel circulating biomarker for detection of gastric cancer. Mol Cancer. 2018;17(1):137

56. Zhao R, Zhang $Y$, Zhang $X$, Yang $Y$, Zheng $X$, Li X, et al. Exosomal long noncoding RNA HOTTIP as potential novel diagnostic and prognostic biomarker test for gastric cancer. Mol Cancer. 2018;17(1):68.

57. Barbagallo C, Brex D, Caponnetto A, Cirnigliaro M, Scalia M, Magnano A, et al. LnCRNA UCA1, upregulated in CRC biopsies and downregulated in serum exosomes, controls mRNA expression by RNA-RNA interactions. Mol Ther Nucleic Acids. 2018;12:229-41.

58. Yan S, Jiang Y, Liang C, Jin C, Duan Q, Xu D, et al. Exosomal miR-6803-5p as potential diagnostic and prognostic marker in colorectal cancer. J Cell Biochem. 2017:119(5):4113-9.

59. Pu C, Huang H, Wang Z, et al. Extracellular vesicle-associated mir-21 and mir-144 are markedly elevated in serum of patients with hepatocellular carcinoma. Front Physiol. 2018;9:930.

60. Xu M. Serum and exosome long non coding RNAs as potential biomarkers for hepatocellular carcinoma. J Cancer. 2018;9(15):2631-9.

61. Xu H, Dong X, Chen $Y$, Wang $X$. Serum exosomal hnRNPH1 mRNA as a novel marker for hepatocellular carcinoma. Clin Chem Lab Med. 2017;56(3):479-84.

62. Zhang C, Yang X, Qi Q, Gao Y, Wei Q, Han S. IncRNA-HEIH in serum and exosomes as a potential biomarker in the HCV-related hepatocellular carcinoma. Cancer Biomarkers. 2018;21(3):651.

63. Ma X, Yuan T, Yang C, Wang Z, Zang Y, Wu L, et al. X-inactive-specific transcript of peripheral blood cells is regulated by exosomal Jpx and acts as a biomarker for female patients with hepatocellular carcinoma. Ther Adv Med Oncol. 2017;9(11):665

64. Skotland T, Ekroos K, Kauhanen D, Simolin H, Seierstad T, Berge V, et al. Molecular lipid species in urinary exosomes as potential prostate cancer biomarkers. Eur J Cancer. 2017;70:122-32.

65. Roberg-Larsen H, Lund K, Seterdal KE, Solheim S, Vehus T, Solberg N, et al. Mass spectrometric detection of 27-hydroxycholesterol in breast cancer exosomes. J Steroid Biochem Mol Biol. 2017;169:22-8.

66. Webber J, Clayton A. How pure are your vesicles? J Extracell Vesicles. 2013; 2(1):19861.

67. Li P, Kaslan M, Lee SH, Yao J, Gao Z. Progress in exosome isolation techniques. Theranostics. 2017;7(3):789-804.

68. Faw C, Brisson AR, Buzas El, Dignat-George F, Eee D, El-Andaloussi S, et al. Methodological guidelines to study extracellular vesicles. Circ Res. 2017; 120(10):1632-48.

69. Baranyai T, Herczeg K, Onodi Z, Voszka I, Modos K, Marton N, et al. Isolation of exosomes from blood plasma: qualitative and quantitative comparison of ultracentrifugation and size exclusion chromatography methods. PLoS One. 2015;10(12):e0145686.

70. Mol EA, Goumans MJ, Doevendans PA, Sluijter JP, Vader P. Higher functionality of extracellular vesicles isolated using size-exclusion chromatography compared to ultracentrifugation. Nanomedicine. 2017.

71. Lai RC, Arslan F, Lee MM, Sze NS, Choo A, Chen TS, et al. Exosome secreted by MSC reduces myocardial ischemia/reperfusion injury. Stem Cell Res. 2010;4(3):214-22.

72. Gholizadeh S, Shehata Draz M, Zarghooni M, Sanati-Nezhad A, Ghavami S, Shafiee $\mathrm{H}$, et al. Microfluidic approaches for isolation, detection, and characterization of extracellular vesicles: current status and future directions. Biosens Bioelectron. 2017:91:588-605.

73. Merchant ML, Powell DW, Wilkey DW, Cummins TD, Deegens JK, Rood IM, et al. Microfiltration isolation of human urinary exosomes for characterization by MS. Proteomics Clin Appl. 2010;4(1):84-96.

74. Wunsch BH, Smith JT, Gifford SM, Wang C, Brink M, Bruce RL, et al. Nanoscale lateral displacement arrays for the separation of exosomes and colloids down to $20 \mathrm{~nm}$. Nat Nanotechnol. 2016;11(11):936-40.

75. Liu C, Guo J, Tian F, Yang N, Yan F, Ding Y, et al. Field-free isolation of exosomes from extracellular vesicles by microfluidic viscoelastic flows. ACS Nano. 2017;11(7):6968-76. 
76. Wu M, Ouyang Y, Wang Z, Zhang R, Huang PH, Chen C, et al. Isolation of exosomes from whole blood by integrating acoustics and microfluidics. Proc Natl Acad Sci U S A. 2017;114(40):10584-9.

77. Stranska R, Gysbrechts L, Wouters J, Vermeersch P, Bloch K, Dierickx D, et al. Comparison of membrane affinity-based method with size-exclusion chromatography for isolation of exosome-like vesicles from human plasma. J Transl Med. 2018;16(1):1.

78. Chen C, Lin BR, Hsu MY, Cheng CM. Paper-based devices for isolation and characterization of extracellular vesicles. Microfluid Nanofluid. 2015;2015(98): 849-56.

79. Yoshida M, Hibino K, Yamamoto S, Matsumura S, Yajima Y, Shiba K. Preferential capture of EpCAM-expressing extracellular vesicles on solid surfaces coated with an aptamer-conjugated zwitterionic polymer. Biotechnol Bioeng. 2018;115(3):536-44.

80. Ghosh A, Davey M, Chute IC, Griffiths SG, Lewis S, Chacko S, et al. Rapid isolation of extracellular vesicles from cell culture and biological fluids using a synthetic peptide with specific affinity for heat shock proteins. PLoS One. 2014;9(10):e110443.

81. Balaj L, Atai NA, Chen W, Mu D, Tannous BA, Breakefield XO, et al. Heparin affinity purification of extracellular vesicles. Sci Rep. 2015;5:10266.

82. Juan E, Felix R, Raquel P, Lorena S, Juan Manuel FP, Niels-Christian R. Microarray-based identification of lectins for the purification of human urinary extracellular vesicles directly from urine samples. Chembiochem. 2014;15(11):1621-6.

83. Gerlach JQ, Maguire CM, Krüger A, Joshi L, Prina-Mello A, Griffin MD. Urinary nanovesicles captured by lectins or antibodies demonstrate variations in size and surface glycosylation profile. Nanomedicine. 2017; 12(11):1217-29

84. Zarovni N, Corrado A, Guazzi P, Zocco D, Lari E, Radano G, et al. Integrated isolation and quantitative analysis of exosome shuttled proteins and nucleic acids using immunocapture approaches. Methods. 2015;87:46-58.

85. Ueda K, Ishikawa N, Tatsuguchi A, Saichi N, Fujii R, Nakagawa H. Antibodycoupled monolithic silica microtips for highthroughput molecular profiling of circulating exosomes. Sci Rep. 2014;4(4):6232.

86. Fang X, Duan Y, Adkins GB, Pan S, Wang H, Liu Y, et al. Highly efficient exosome isolation and protein analysis by integrated nanomaterial-based platform. Anal Chem. 2018;90(4):acs.analchem.7b04861.

87. Cai S, Luo B, Jiang P, Zhou X, Lan F, Yi Q, et al. Immuno-modified superparamagnetic nanoparticles via host-guest interactions for highpurity capture and mild release of exosomes. Nanoscale. 2018;10(29): 14280-9.

88. Jauregui R, Srinivasan S, Vojtech LN, Gammill HS, Chiu DT, Hladik F, et al. Temperature-responsive magnetic nanoparticles for enabling affinity separation of extracellular vesicles. ACS Appl Mater Interfaces. 2018;10(40): 33847-56.

89. Tauro BJ, Greening DW, Mathias RA, Ji H, Mathivanan S, Scott AM, et al. Comparison of ultracentrifugation, density gradient separation, and immunoaffinity capture methods for isolating human colon cancer cell line LIM1863-derived exosomes. Methods. 2012;56(2):293-304.

90. Jorgensen M, Baek R, Pedersen S, Sondergaard EK, Kristensen SR, Varming K. Extracellular Vesicle (EV) Array: microarray capturing of exosomes and other extracellular vesicles for multiplexed phenotyping. J Extracell Vesicles. 2013; 2:20920.

91. Kaushik AM, Hsieh K, Wang T-H. Droplet microfluidics for high-sensitivity and high-throughput detection and screening of disease biomarkers. Wiley Interdiscip Rev Nanomed Nanobiotechnol. 2018;10(6):e1522.

92. Joy AP, Ayre DC, Chute IC, Beauregard AP, Wajnberg G, Ghosh A, et al Proteome profiling of extracellular vesicles captured with the affinity peptide Vn96: comparison of laemmli and TRIzol@ protein-extraction methods. J Extracellular Vesicles. 2018;7(1):1438727.

93. Knol JC, Reus ID, Schelfhorst T, Beekhof R, Wit MD, Piersma SR, et al. Peptide-mediated 'miniprep' isolation of extracellular vesicles is suitable for high-throughput proteomics. Eupa Open Proteomics. 2016;11(C):11-5.

94. Tamura R, Yin H. Rationally designed peptide probes for extracellular vesicles. Adv Clin Chem. 2016;79:25

95. Anne-Laure R, Jessica G, Aurelie DT, Elise S, Jean Paul PDB, Arlette H, et al. Peptides and aptamers targeting HSP70: a novel approach for anticancer chemotherapy. Cancer Res. 2011;71(2):484-95.

96. Carney RP, Hazari S, Rojalin T, Knudson A, Gao T, Tang Y, et al. Targeting tumor-associated exosomes with integrin-binding peptides. Adv Biosyst. 2017;1(5):1600038.
97. Hongguang S, Youli Z. A highlight of recent advances in aptamer technology and its application. Molecules. 2015;20(7):11959-80.

98. Wan Y, Cheng G, Liu X, Hao S-J, Nisic M, Zhu C-D, et al. Rapid magnetic isolation of extracellular vesicles via lipid-based nanoprobes. Nat Biomed Eng. 2017;1(4):1-11.

99. Liyun $X$, Jianni Q, Peiqing Z, Xiaohong L, Ying J, Peng $L$, et al. T cell immunoglobulin- and mucin-domain-containing molecule-4 attenuates concanavalin A-induced hepatitis by regulating macrophage. J Leukoc Biol. 2010;88(2):329-36

100. Katarina T, Chieh H, Salvatore C, Lawrence R, Dirk W, Felix W, et al. Ceramide triggers budding of exosome vesicles into multivesicular endosomes. Science. 2008;319(5867):1244-7.

101. Yoshida T, Ishidome T, Hanayama R. High purity isolation and sensitive quantification of extracellular vesicles using affinity to TIM4: extracellular vesicle isolation and purification using TIM4 affinity; 2017.

102. Lemmon M. Membrane recognition by phospholipid-binding domains. Nat Rev Mol Cell Biol. 2008;9(2):99.

103. Atai NA, Leonora B, Henk W, Breakefield XO, Jarzyna PA, Noorden CJF. Van et al. Heparin blocks transfer of extracellular vesicles between donor and recipient cells. J Neuro-Oncol. 2013;115(3):343-51.

104. Ibsen SD, Wright J, Lewis JM, Kim S, Ko SY, Ong J, et al. Rapid isolation and detection of exosomes and associated biomarkers from plasma. ACS Nano. 2017;11(7):6641-51.

105. Zakharova L, Svetlova M, Fomina AF. T cell exosomes induce cholesterol accumulation in human monocytes via phosphatidylserine receptor. J Cell Physiol. 2007;212(1):174-81.

106. Chen J, Xu Y, Lu Y, Xing W. Rapid isolation and visible detection of tumorderived exosomes from plasma. Anal Chem. 2018;90(24):14207-15.

107. Caradec J, Kharmate G, Hosseini-Beheshti E, Adomat H, Gleave M, Guns E. Reproducibility and efficiency of serum-derived exosome extraction methods. Clin Biochem. 2014;47(13-14):1286-92.

108. Greening DW, Xu R, Ji H, Tauro BJ, Simpson RJ. A protocol for exosome isolation and characterization: evaluation of ultracentrifugation, densitygradient separation, and immunoaffinity capture methods. In: Posch A, editor. Proteomic profiling: methods and protocols. New York: Springer New York; 2015. p. 179-209.

109. Boriachek K, Islam MN, Möller A, Salomon C, Nguyen NT, Msa H, et al. Biological functions and current advances in isolation and detection strategies for exosome nanovesicles. Small. 2017;14(6):1702153.

110. Peterson MF, Otoc N, Sethi JK, Gupta A, Antes TJ. Integrated systems for exosome investigation. Methods. 2015;87:S1046202315001619.

111. Alvarez ML, Mahdieh K, Rupesh KR, Distefano JK. Comparison of protein, microRNA, and mRNA yields using different methods of urinary exosome isolation for the discovery of kidney disease biomarkers. Kidney Int. 2012; 82(9):1024.

112. Rider MA, Hurwitz SN, Meckes DG Jr. ExtraPEG: a polyethylene glycol-based method for enrichment of extracellular vesicles. Sci Rep. 2016;6:23978.

113. Taylor DD, Zacharias W, Gercel-Taylor C. Exosome isolation for proteomic analyses and RNA profiling. Methods Mol Biol. 2011;728(728):235.

114. Wu M, Ouyang Y, Wang Z, Zhang R, Huang PH, Chen C, et al. Isolation of exosomes from whole blood by integrating acoustics and microfluidics. Proc Natl Acad Sci U S A. 2017;114(40):201709210.

115. Nakai W, Yoshida T, Diez D, Miyatake Y, Nishibu T, Imawaka N, et al. A novel affinity-based method for the isolation of highly purified extracellular vesicles. Sci Rep. 2016;6:33935.

116. Sodar BW, Kittel A, Paloczi K, Vukman KV, Osteikoetxea X, Szabo-Taylor K, et al. Low-density lipoprotein mimics blood plasma-derived exosomes and microvesicles during isolation and detection. Sci Rep. 2016;6:24316.

117. Witwer KW, Soekmadji C, Hill AF, Wauben MH, Buzas El, Di Vizio D, et al. Updating the MISEV minimal requirements for extracellular vesicle studies: building bridges to reproducibility. J Extracell Vesicles. 2017;6(1):1396823.

118. Franquesa M, Hoogduijn MJ, Ripoll E, Luk F, Salih M, Betjes MGH, et al. Update on controls for isolation and quantification methodology of extracellular vesicles derived from adipose tissue mesenchymal stem cells. Front Immunol. 2014;5(5):525.

119. Zhu L, Wang K, Cui J, Liu H, Bu X, Ma H, et al. Label-free quantitative detection of tumor-derived exosomes through surface plasmon resonance imaging. Anal Chem. 2014;86(17):8857-64.

120. Khatun Z, Bhat A, Sharma S, Sharma A. Elucidating diversity of exosomes: biophysical and molecular characterization methods. Nanomedicine. 2016 11(17):2359-77. 
121. Filella M, Zhang J, Newman ME, Buffle J. Analytical applications of photon correlation spectroscopy for size distribution measurements of natural colloidal suspensions: capabilities and limitations. Colloids Surf A Physicochem Eng Aspects. 1997;120(1-3):27-46.

122. Chia BS, Low YP, Wang Q, Li P, Gao Z. Advances in exosome quantification techniques. TrAC Trends Anal Chem. 2016;86:93-106.

123. Shao H, Im H, Castro CM, Breakefield X, Weissleder R, Lee H. New technologies for analysis of extracellular vesicles. Chem Rev. 2018;118(4):acs. chemrev.7b00534.

124. Lannigan J, Erdbruegger U. Imaging flow cytometry for the characterization of extracellular vesicles. Methods. 2017;112:55.

125. Supplement C. Abstracts from the Third International Meeting of ISEV 2014 Rotterdam, The Netherlands, April 30th - May 3rd, 2014. J Extracellular Vesicles. 2014;3:1-156.

126. Valkonen S, Pol EVD, Böing A, Yuana Y, Yliperttula M, Nieuwland R, et al. Biological reference materials for extracellular vesicle studies. Eur J Pharm Sci. 2017;98:4-16.

127. Stoner SA, Duggan E, Condello D, Guerrero A, Turk JR, Narayanan PK, et al. High sensitivity flow cytometry of membrane vesicles. Cytometry A. 2016; 89(2):196-206.

128. Kormelink TG, Arkesteijn GJA, Nauwelaers FA, Engh GVD, Hoen ENMNT, Wauben MHM. Prerequisites for the analysis and sorting of extracellular vesicle subpopulations by high-resolution flow cytometry. Cytometry Part A. 2016;89(2):135-47

129. Supplement C. The Fifth International Meeting of ISEV, ISEV2016, Rotterdam, The Netherlands, 4-7 May, 2016. J Extracellular Vesicles. 2016;5:31552.

130. Gupta S, Knowlton AA. HSP60 trafficking in adult cardiac myocytes: role of the exosomal pathway. Am J Physiol Heart Circ Physiol. 2007;292(6):H3052-6.

131. Savina A, Vidal M, Colombo MI. The exosome pathway in K562 cells is regulated by Rab11. J Cell Sci. 2002;115(12):2505-15.

132. Koritzinsky EH, Street JM, Star RA, Yuen PS. Quantification of exosomes. J Cell Physiol. 2017;232(7):1587-90.

133. Musante L, Tataruch-Weinert D, Kerjaschki D, Henry M, Meleady P, Holthofer $H$. Residual urinary extracellular vesicles in ultracentrifugation supernatants after hydrostatic filtration dialysis enrichment. J Extracell Vesicles. 2017;6(1): 1267896.

134. Foster BP, Balassa T, Benen TD, Dominovic M, Elmadjian GK, Florova V, et al. Extracellular vesicles in blood, milk and body fluids of the female and male urogenital tract and with special regard to reproduction. Crit Rev Clin Lab Sci. 2016;53(6):379-95.

135. He F, Liu H, Guo X, Yin BC, Ye BC. Direct exosome quantification via bivalent-cholesterol-labeled DNA anchor for signal amplification. Anal Chem. 2017;89(23):12968-75.

136. Tian Q, He C, Liu G, Zhao Y, Hui L, Mu Y, et al. Nanoparticle counting by microscopic digital detection: selective quantitative analysis of exosomes via surface-anchored nucleic acid amplification. Anal Chem. 2018;90(11):6556-62.

137. Boriachek K, Islam MN, Gopalan V, Lam AK, Nguyen NT, Shiddiky MJA. Quantum dot-based sensitive detection of disease specific exosome in serum. Analyst. 2017;142(12):2211-9.

138. Liu C, Xu X, Li B, Situ B, Pan W, Hu Y, et al. Single-exosome-counting immunoassays for cancer diagnostics. Nano Lett. 2018;18(7):4226-32.

139. Pugholm LH, Revenfeld AL, Søndergaard EK, Jørgensen MM. Antibodybased assays for phenotyping of extracellular vesicles. Biomed Res Int. 2015; 2015(8):524817.

140. Assarsson E, Lundberg M, Holmquist G, Björkesten J, Thorsen SB, Ekman D, et al. Homogenous 96-plex PEA immunoassay exhibiting high sensitivity, specificity, and excellent scalability. PLoS One. 2014;9(4):e95192.

141. Grasso L, Wyss R, Weidenauer L, Thampi A, Demurtas D, Prudent M, et al. Molecular screening of cancer-derived exosomes by surface plasmon resonance spectroscopy. Anal Bioanal Chem. 2015;407(18):1-8.

142. Im H, Shao H, Park Yl, Peterson VM, Castro CM, Weissleder R, et al. Label-free detection and molecular profiling of exosomes with a nano-plasmonic sensor. Nat Biotechnol. 2014;32(5):490-5.

143. Rupert DL, Lässer C, Eldh M, Block S, Zhdanov VP, Lotvall JO, et al. Determination of exosome concentration in solution using surface plasmon resonance spectroscopy. Anal Chem. 2014;86(12):5929-36.

144. Zhu L, Wang K, Cui J, Liu H, Bu X, Ma H, et al. Label-free quantitative detection of tumor-derived exosomes through surfaceplasmon resonance imaging. Anal Chem. 2014;86(17):8857-64.

145. Richard BM, Schasfoort AJT. Handbook of surface plasmon resonance. London: Royal Society of Chemistry; 2008.
146. Jorgensen MM, Baek R, Varming K. Potentials and capabilities of the extracellular vesicle (EV) array. J Extracell Vesicles. 2015;4:26048.

147. Duijvesz D, Versluis CYL, Van dF, Christa AM, Leivo J, Peltola MT, Bangma $\mathrm{CH}$, et al. Immuno-based detection of extracellular vesicles in urine as diagnostic marker for prostate cancer. Int J Cancer. 2015; 137(12):2869-78.

148. He M, Crow J, Roth M, Zeng Y, Godwin AK. Integrated immunoisolation and protein analysis of circulating exosomes using microfluidic technology. Lab Chip. 2014;14(19):3773-80

149. Yoshioka Y, Kosaka N, Konishi Y, Ohta H, Okamoto H, Sonoda H, et al. Ultrasensitive liquid biopsy of circulating extracellular vesicles using ExoScreen. Nat Commun. 2014;5(4):3591.

150. Shao H, Chung J, Balaj L, Weissleder R, Lee H. Protein typing of circulating microvesicles allows real-time monitoring of glioblastoma therapy. APS March Meeting; 2013.

151. Haun JB, Castro CM, Wang R, Peterson VM, Marinelli BS, Lee H, et al. MicroNMR for rapid molecular analysis of human tumor samples. Sci Transl Med. 2011;3(71):71ra16.

152. Park J, Lin HY, Assaker JP, Jeong S, Huang CH, Kurdi A, et al. Integrated kidney exosome analysis (iKEA) for the detection of kidney transplant rejection. ACS Nano. 2017;11(11):11041-6.

153. Xu H, Liao C, Zuo P, Liu Z, Ye BC. Magnetic-based microfluidic device for on-chip isolation and detection of tumor-derived exosomes. Anal Chem. 2018.

154. Chen Z, Cheng SB, Cao P, Qiu QF, Chen Y, Xie M, et al. Detection of exosomes by $\mathrm{ZnO}$ nanowires coated three-dimensional scaffold chip device. Biosens Bioelectron. 2018;122:211-6.

155. Li T-D, Zhang R, Chen H, Huang Z-P, Ye X, Wang H, et al. An ultrasensitive polydopamine bi-functionalized SERS immunoassay for exosome-based diagnosis and classification of pancreatic cancer. Chem Sci. 2018;9(24):5372-82

156. Kabe Y, Suematsu M, Sakamoto S, Hirai M, Koike I, Hishiki T, et al. Development of a highly sensitive device for counting the number of disease-specific exosomes in human sera. Clin Chem. 2018.

157. Yadav S, Boriachek K, Islam N, Lobb R, Möller A, Hill M, et al. An electrochemical method for the detection of disease specific exosomes. ChemElectroChem. 2016;4(4):967-71.

158. Lobb RJ, Becker M, Wen SW, Wong CS, Wiegmans AP, Leimgruber A, et al. Optimized exosome isolation protocol for cell culture supernatant and human plasma. J Extracell Vesicles. 2015;4:27031.

159. Lewis JM, Vyas AD, Qiu Y, Messer KS, White R, Heller MJ. Integrated analysis of exosomal protein biomarkers on alternating current electrokinetic chips enables rapid detection of pancreatic cancer in patient blood. ACS Nano. 2018;12(4):3311-20.

160. Park J, Im H, Hong S, Castro CM, Weissleder R, Lee H. Analyses of intravesicular exosomal proteins using a nano-plasmonic system. ACS Photonics. 2018;5(2):487-94.

161. Smith ZJ, Lee C, Rojalin T, Carney RP, Hazari S, Knudson A, et al. Single exosome study reveals subpopulations distributed among cell lines with variability related to membrane content. J Extracellular Vesicles. 2015;4(1):28533.

162. Tatischeff I, Larquet E, Falcón-Pérez JM, Turpin PY, Kruglik SG. Fast characterisation of cell-derived extracellular vesicles by nanoparticles tracking analysis, cryo-electron microscopy, and Raman tweezers microspectroscopy. J Extracellular Vesicles. 2012;1:19179.

163. Carney RP, Hazari S, Colquhoun M, Tran D, Hwang B, Mulligan MS, et al. Multispectral optical tweezers for biochemical fingerprinting of CD9-positive exosome subpopulations. Anal Chem. 2017;89(10):5357-63.

164. Uzunbajakava N, Lenferink A, Kraan Y, Volokhina E, Vrensen G, Greve J, et al. Nonresonant confocal Raman imaging of DNA and protein distribution in apoptotic cells. Biophys J. 2003;84(6):3968-81.

165. Puppels GJ, Colier W, Olminkhof JHF, Otto C, Mul FFMD, Greve J. Description and performance of a highly sensitive confocal Raman microspectrometer. J Raman Spectrosc. 1991;22(4):217-25.

166. Pol EVD, Hoekstra AG, Sturk A, Otto C, Leeuwen TGV, Nieuwland R. Optical and non-optical methods for detection and characterization of microparticles and exosomes. J Thromb Haemost. 2010;8(12):2596-607.

167. van der Pol E, Coumans F, Varga Z, Krumrey M, Nieuwland R. Innovation in detection of microparticles and exosomes. J Thromb Haemost. 2013;11(s1): $36-45$.

168. Stremersch S, Marro M, Pinchasik BE, Baatsen P, Hendrix A, De Smedt SC, et al. Identification of individual exosome-like vesicles by surface enhanced raman spectroscopy. Small. 2016;12(24):3292-301. 
169. Park J, Hwang M, Choi B, Jeong H, Jung JH, Kim HK, et al. Exosome classification by pattern analysis of surface-enhanced raman spectroscopy data for lung cancer diagnosis. Anal Chem. 2017;89(12):6695-701.

170. Carmicheal J, Hayashi C, Huang X, Liu L, Lu Y, Krasnoslobodtsev A, et al. Label-free characterization of exosome via surface enhanced Raman spectroscopy for the early detection of pancreatic cancer. Nanomedicine. 2018;16:88-96.

171. Wang Z, Zong S, Wang Y, Li N, Li L, Lu J, et al. Screening and multiple detection of cancer exosomes using an SERS-based method. Nanoscale. 2018;10(19):9053-62.

172. Jiang Y, Shi M, Liu Y, Wan S, Cui C, Zhang L, et al. Aptamer/AuNP biosensor for colorimetric profiling of exosomal proteins. Angew Chem Int Ed Eng. 2017;56(39):11916-20.

173. Hensley P. SOMAmers and SOMAscan - a protein biomarker discovery platform for rapid analysis of sample collections from bench top to the clinic. J Biomol Tech. 2013;26(2):140-62.

174. Webber J, Stone TC, Katilius E, Smith BC, Gordon B, Mason MD, et al. Proteomics analysis of cancer exosomes using a novel modified aptamer-based array (SOMAscan ${ }^{\mathrm{TM}}$ ) platform. Mol Cell Proteomics. 2014 13(4):1050-64

175. Gold L, Walker JJ, Wilcox SK, Williams S. Advances in human proteomics at high scale with the SOMAscan proteomics platform. New Biotechnol. 2012; 29(5):543-9.

176. Baird GS, Nelson SK, Keeney TR, Stewart A, Williams S, Kraemer S, et al. Agedependent changes in the cerebrospinal fluid proteome by slow off-rate modified aptamer array. Am J Pathol. 2012;180(2):446-56.

177. Zichi D, Eaton B, Singer B, Gold L. Proteomics and diagnostics: let's get specific, again. Curr Opin Chem Biol. 2008;12(1):78-85.

178. Thery C, Boussac M, Veron P, Ricciardi-Castagnoli P, Raposo G, Garin J, et al. Proteomic analysis of dendritic cell-derived exosomes: a secreted subcellular compartment distinct from apoptotic vesicles. J Immunol. 2001;166(12): 7309-18.

179. Wang Z, Hill S, Luther JM, Hachey DL, Schey KL. Proteomic analysis of urine exosomes by multidimensional protein identification technology (MudPIT). Proteomics. 2012;12(2):329-38.

180. Wisniewski JR, Zougman A, Nagaraj N, Mann M. Universal sample preparation method for proteome analysis. Nat Methods. 2009;6(5):359-62.

181. Choi DS, Kim DK, Kim YK, Gho YS. Proteomics of extracellular vesicles: exosomes and ectosomes. Mass Spectrom Rev. 2015;34(4):474-90.

182. Aswad H, Jalabert A, Rome S. Depleting extracellular vesicles from fetal bovine serum alters proliferation and differentiation of skeletal muscle cells in vitro. BMC Biotechnol. 2016;16:32.

183. Eitan E, Zhang S, Witwer KW, Mattson MP. Extracellular vesicle-depleted fetal bovine and human sera have reduced capacity to support cell growth. J Extracell Vesicles. 2015;4:26373.

184. Mitchell JP, Court J, Mason MD, Tabi Z, Clayton A. Increased exosome production from tumour cell cultures using the integra CELLine culture system. J Immunol Methods. 2008;335(1-2):98-105.

185. Kalra H, Simpson RJ, Ji H, Aikawa E, Altevogt $P$, Askenase $P$, et al. Vesiclepedia: a compendium for extracellular vesicles with continuous community annotation. PLoS Biol. 2012;10:e1001450.

186. Kim DK, Lee J, Kim SR, Choi DS, Yoon YJ, Kim JH, et al. EVpedia: a community web portal for extracellular vesicles research. Bioinformatics. 2015;31(6):933-9.

187. Akers JC, Ramakrishnan V, Kim R, Skog J, Nakano I, Pingle S, et al. MiR-21 in the extracellular vesicles (EVs) of cerebrospinal fluid (CSF): a platform for glioblastoma biomarker development. PLoS One. 2013;8(10):e78115.

188. Coumans FAW, Brisson AR, Buzas El, Dignat-George F, Drees EEE, ElAndaloussi $\mathrm{S}$, et al. Methodological guidelines to study extracellular vesicles. Circ Res. 2017;120(10):1632-48.

189. Xiao D, Ohlendorf J, Chen Y, Taylor DD, Rai SN, Waigel S, et al. Identifying mRNA, microRNA and protein profiles of melanoma exosomes. PLoS One. 2012;7(10):e46874

190. Ji HL, Kim JA, Jeong S, Rhee WJ. Simultaneous and multiplexed detection of exosome microRNAs using molecular beacons. Biosens Bioelectron. 2016;86: 202-10

191. Ji HL, Kim JA, Min HK, Ji YK, Rhee WJ. In situ single step detection of exosome microRNA using molecular beacon. Biomaterials. 2015;54:116-25.

192. Piatek AS, Tyagi S, Pol AC, Telenti A, Miller LP, Kramer FR, et al. Molecular beacon sequence analysis for detecting drug resistance in Mycobacterium tuberculosis. Nat Biotechnol. 1998;16(4):359.
193. Lee LJ, Yang Z, Rahman M, Ma J, Kwak KJ, Mcelroy J, et al. Extracellular mRNA detected by tethered lipoplex nanoparticle biochip for lung adenocarcinoma detection. Am J Respir Crit Care Med. 2016;193(12): 1431-3.

194. Rhee WJ, Jeong S. Extracellular vesicle miRNA detection using molecular beacons. Methods Mol Biol. 2017;1660:287-94

195. Lee J, Kwon MH, Kim JA, Rhee WJ. Detection of exosome miRNAs using molecular beacons for diagnosing prostate cancer. Artif Cells Nanomed Biotechnol. 2018;46(sup3):S52-63.

196. Wenk MR. Lipidomics: new tools and applications. Cell. 2010;143(6):888-95.

197. Jung HR, Sylvanne T, Koistinen KM, Tarasov K, Kauhanen D, Ekroos K. High throughput quantitative molecular lipidomics. Biochim Biophys Acta. 2011; 1811(11):925-34

198. Wang M, Wang C, Han RH, Han X. Novel advances in shotgun lipidomics for biology and medicine. Prog Lipid Res. 2016:61:83-108.

199. Schuhmann K, Herzog R, Schwudke D, Metelmann-Strupat W, Bornstein SR, Shevchenko A. Bottom-up shotgun lipidomics by higher energy collisional dissociation on LTQ Orbitrap mass spectrometers. Anal Chem. 2011;83(14): 5480-7.

200. Del Boccio P, Raimondo F, Pieragostino D, Morosi L, Cozzi G, Sacchetta P, et al. A hyphenated microLC-Q-TOF-MS platform for exosomal lipidomics investigations: application to RCC urinary exosomes. Electrophoresis. 2012; 33(4):689-96.

201. Machado E, Kandzia S, Carilho R, Altevogt P, Conradt HS, Costa J. NGlycosylation of total cellular glycoproteins from the human ovarian carcinoma SKOV3 cell line and of recombinantly expressed human erythropoietin. Glycobiology. 2011;21(3):376-86.

202. Meldolesi J. Exosomes and ectosomes in intercellular communication. Curr Biol. 2018;28(8):R435-R44.

203. Mashouri L, Yousefi H, Aref AR, Ahadi AM, Molaei F, Alahari SK. Exosomes: composition, biogenesis, and mechanisms in cancer metastasis and drug resistance. Mol Cancer. 2019;18(1):75.

\section{Publisher's Note}

Springer Nature remains neutral with regard to jurisdictional claims in published maps and institutional affiliations. 